Portland State University

PDXScholar

\title{
Aphrodite of Knidos, Trendsetter: Depictions of the Female Nude and Sexuality in Ancient Greek Sculpture
}

Krista Buell

Portland State University

Follow this and additional works at: https://pdxscholar.library.pdx.edu/honorstheses Let us know how access to this document benefits you.

\section{Recommended Citation}

Buell, Krista, "Aphrodite of Knidos, Trendsetter: Depictions of the Female Nude and Sexuality in Ancient Greek Sculpture" (2016). University Honors Theses. Paper 252.

https://doi.org/10.15760/honors.265

This Thesis is brought to you for free and open access. It has been accepted for inclusion in University Honors Theses by an authorized administrator of PDXScholar. Please contact us if we can make this document more accessible: pdxscholar@pdx.edu. 
Aphrodite of Knidos, Trendsetter:

Depictions of the Female Nude and Sexuality in Ancient Greek Sculpture

by

Krista Buell

An undergraduate honors thesis submitted in partial fulfillment of the requirements for the degree of

Bachelor of Arts

in

University Honors

and

Art History

Thesis Adviser

Susanne Tringali

Portland State University

2016 


\section{Contents}

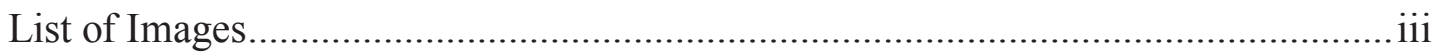

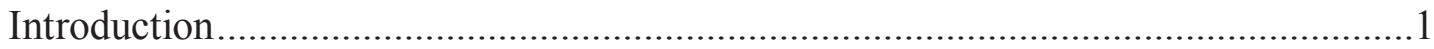

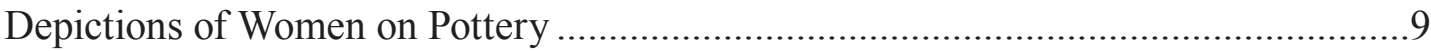

The History of Aphrodite of Knidos .................................................................. 11

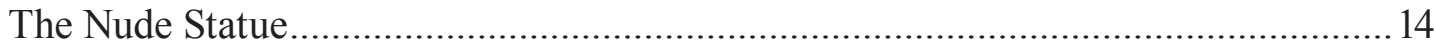

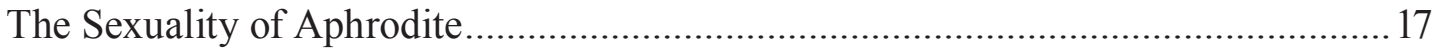

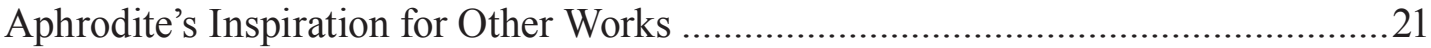

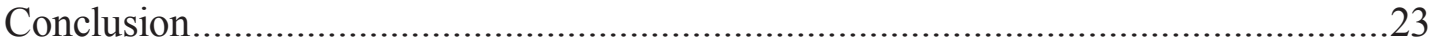

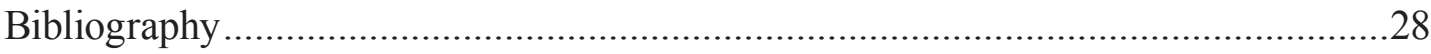

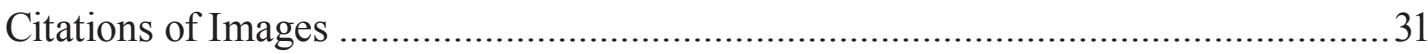




\section{List of Images}

Buell iii

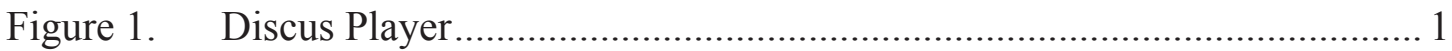

Figure 2. Pankration Foul ............................................................................. 2

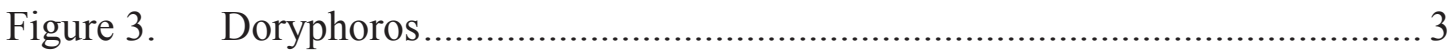

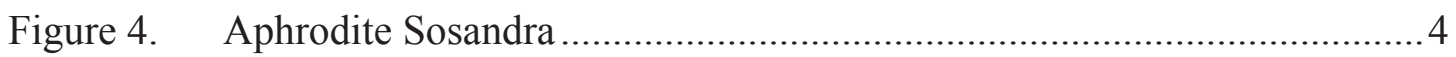

Figure 5. Aphrodite of Knidos (front view)........................................................5

Figure 6. Aphrodite of Knidos (back view) ........................................................ 6

Figure 7. Aphrodite of Knidos (side view) ...........................................................

Figure 8. Woman Playing a Game ................................................................

Figure 9. Three Women Bathing........................................................................ 10

Figure 10. Roman coin depicting the Aphrodite of Knidos...................................... 12

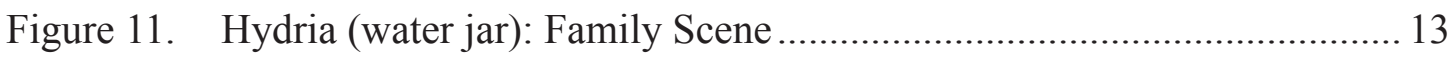

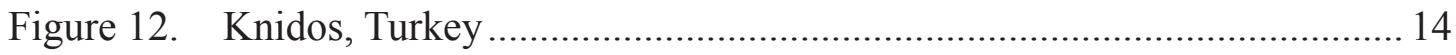

Figure 13. Kylix depicting Ajax the Lesser Raping Cassandra ................................. 15

Figure 14. Kylix depicting Greek scene of erotisicm and violence............................15

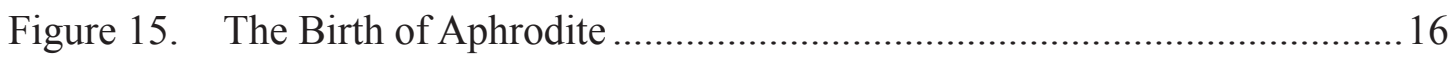

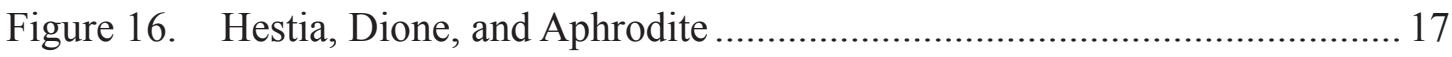

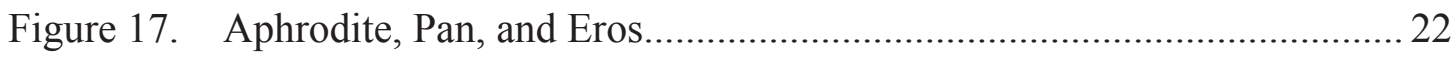

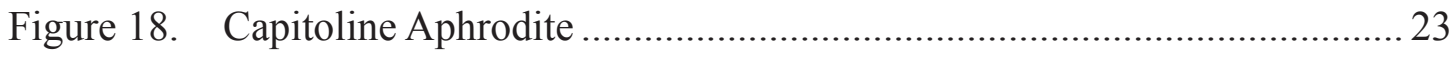

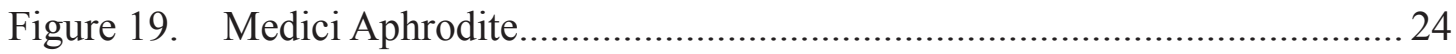

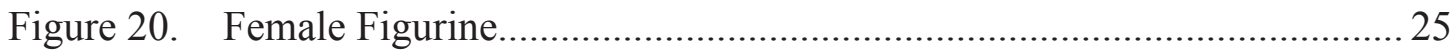

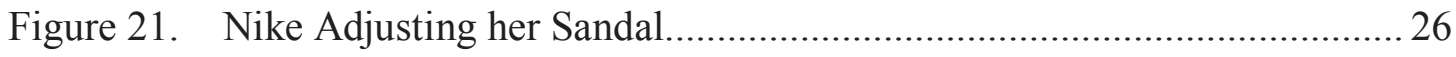

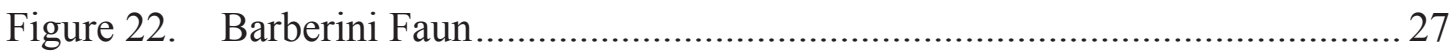




\section{Introduction}

The ancient Greeks viewed the nude form very differently than we do today, wherein the male nude was the ideal form. While clothed women were depicted in ancient times, female nudes — especially in monumental statue form-were rare in comparison to the countless male nudes. In contrast with how the male nude was so admired in ancient times, today it seems taboo for a man to enjoy the image of the male form. ${ }^{1}$ Perhaps this admiration of the male body relates to male homosexuality, which was common and acceptable to the Greeks. Furthermore, the Olympic games were performed and watched entirely by men, while

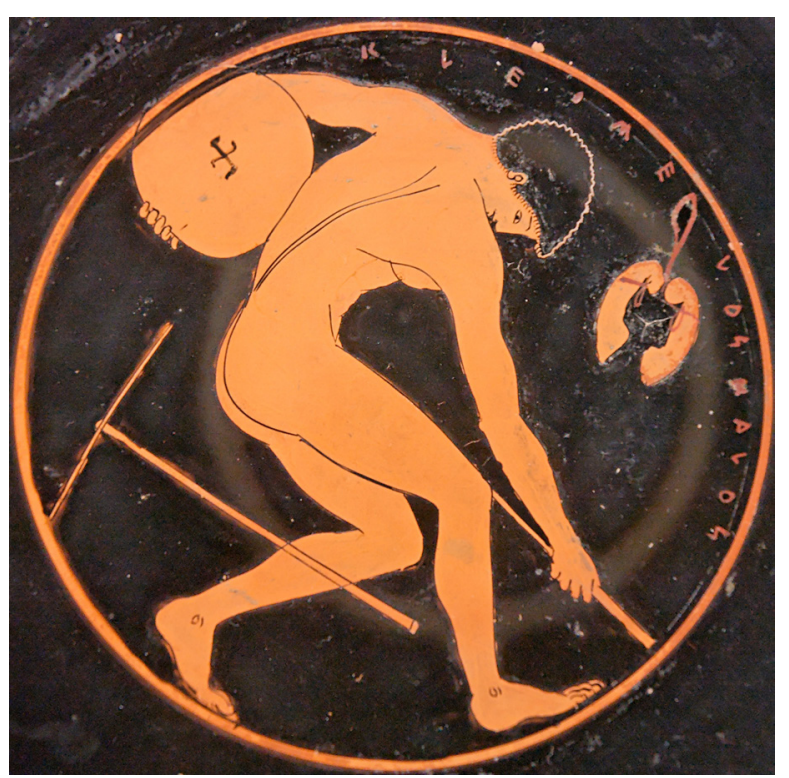

Figure 1. Kleomelos Painter, Discus Player. competing participants played the various sports naked as a means of displaying feats of strength (fig.1 and 2). Greeks thought that women were created as secondary, opposing forces to men, and their existence was primarily necessary for reproduction. ${ }^{2}$ Thus the male form was the supreme embodiment of beauty for the Greeks, and as such became the perfect model for art, which can be seen with the Doryphoros (fig. 3), the quintessential Classical Greek work of art. This left the female form, especially the nude, mostly ignored.

1 Beth A. Eck, "Men Are Much Harder: Gendered Viewing of Nude Images," Gender and Society 17, No. 5 (2003): 693, accessed Oct. 30, 2015, http://www.jstor.org/ stable/3594705.

2 Mireille M. Lee, Body, Dress, and Identity in Ancient Greece, (New York: Cambridge University Press, 2015), 82, accessed Mar. 10, 2016, http://orbis.eblib.com.proxy.lib.pdx.edu. 
With the belief that women were created secondary to men, Greek society was indeed restrictive toward women. Greeks were especially appalled by female bodily functions, such as childbirth, nursing, and menstruation, and it was considered taboo for men to touch women during these times. ${ }^{3}$ Premarital sex was restricted to prostitutes or women of low class. For a woman outside of these low social classes, extreme consequences could ensue if she had sex before marriage, including slavery or

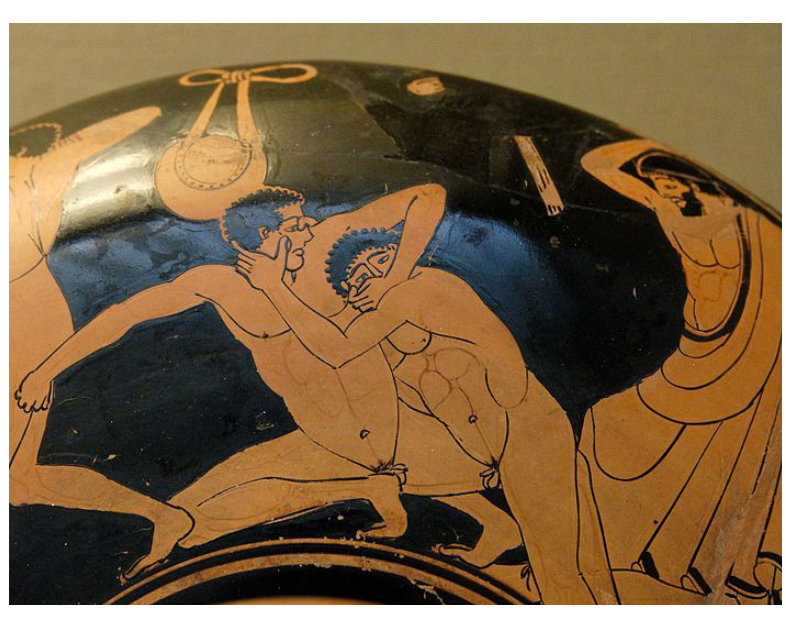

Figure 2. Foundry Painter, Pankration Foul (kylix). death. ${ }^{4}$ In ancient Greece, young men were taught that their virtue stemmed from self-control, whereas women's virtue came from being obedient. ${ }^{5}$ Women were thought to be unable to control themselves, so men had to do it for them. As a whole, women had a relatively low social rank. While men and women were both considered

citizens, men commanded all the authority because they were deemed more fit for the role than women. ${ }^{6}$ In this regard, a woman ranked only slighter higher than a slave, since a slave was considered to have "no deliberative faculty,"7 whereas a woman did; she only lacked authority.

3 Zainab Bahrani, "The Hellenization of Ishtar: Nudity, Fetishism, and the Production of Cultural Differentiation in Ancient Art," Oxford Art Journal 19, no. 2 (1996): 5, accessed Oct. 22, 2015, http://www. jstor.org/stable/1360725. Greeks thought that these bodily functions were unclean and dangerous to men.

4 Guilia Sissa, "Maidenhood without Maidenhead: The Female Body in Ancient Greece," in Before Sexuality: The Construction of Erotic Experience in the Ancient Greek World, edited by David M. Halperin, John J. Winkler, and Froma I. Zeitlin (Princeton, N.J.: Princeton University Press, 1990), 348.

5 Nanette Salomon, "Making a World of Difference" in Naked Truths: Women, Sexuality, and Gender in Classical Art and Archaeology, edited by Ann Olga Koloski-Ostrow, and Claire L. Lyons (London: Routledge, 1997), 210.

6 Mary R. Lefkowitz and Maureen B. Fant, Women's life in Greece and Rome (Baltimore: Johns Hopkins University Press, 1982), 63.

7 Ibid., 64. 
Buell 3

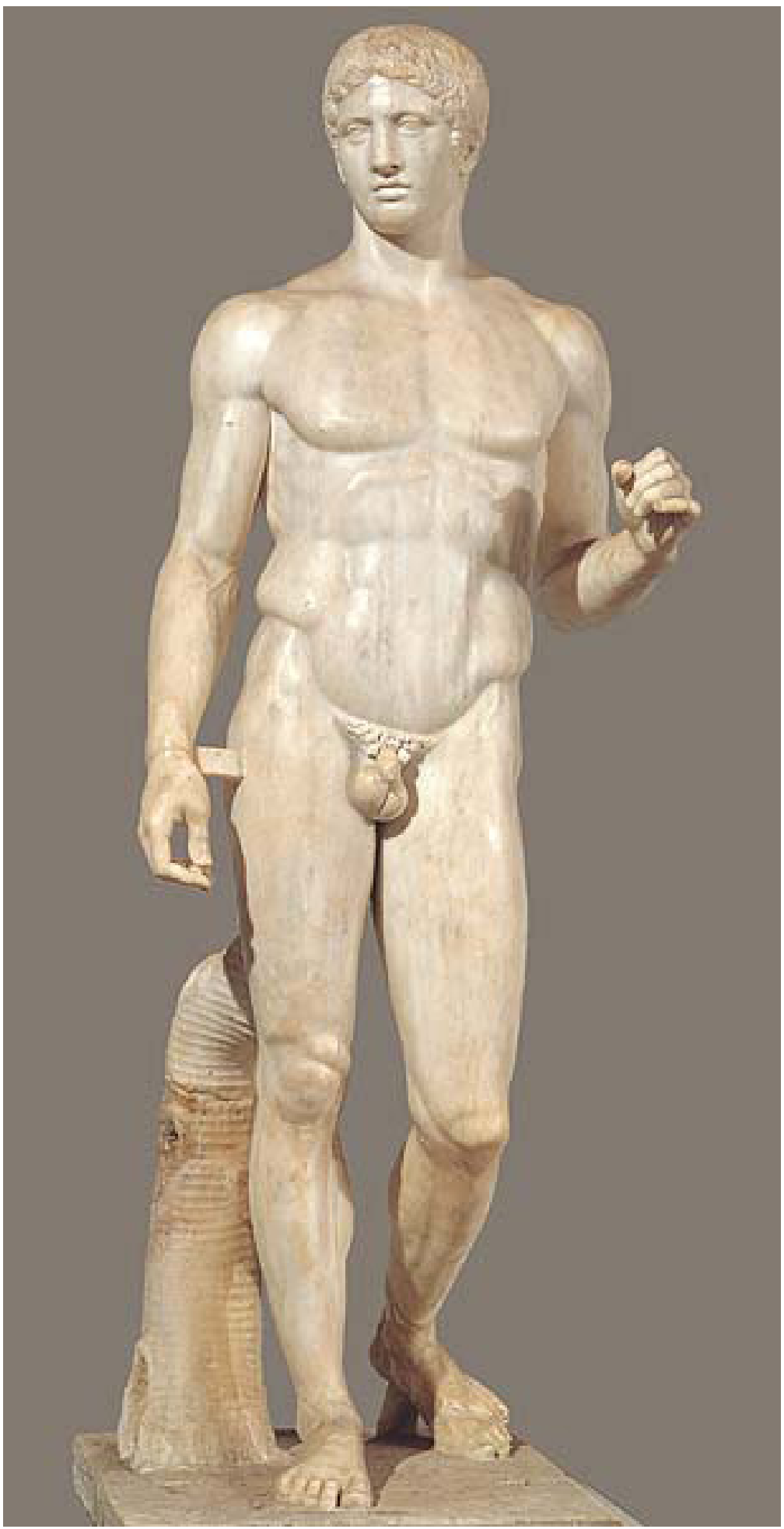

Figure 3. Doryphoros. 
However, in the realm of religion, these rules did not necessarily apply. For example, Aphrodite was the Goddess of Love and therefore exempt from all the mortal trappings and societal restrictions of Greek women. Images of Aphrodite were found in many places, such as cultic sites, in people's homes, in personal gardens, or even by tombs. ${ }^{8}$ This shows how important she was as a goddess to the people of the time. Not only did the numerous locations of her depictions indicate her significance, but also countless dedications to the goddess showed her extreme importance. Families gave rich offerings to Aphrodite on behalf of their female family members, and women themselves dedicated their money to pay homage to the goddess. ${ }^{9}$

Oddly, considering that she was a goddess who embodied love, sexuality, beauty, and femininity, Aphrodite had never been depicted nude in ancient Greek art prior to the mid-fourth century BCE. The Aphrodite Sosandra provides a great example of the clothed goddess (fig. 4). In this sculpture, Aphrodite is covered head to foot with only her face, hand, and parts of her feet showing. This depiction of the Goddess of Love shows no hint of embracing her femininity or sexuality. This all changed when, between 360-330 все, Praxiteles created the now-famous statue known as the Aphrodite of Knidos (figs. 5, 6, and 7).

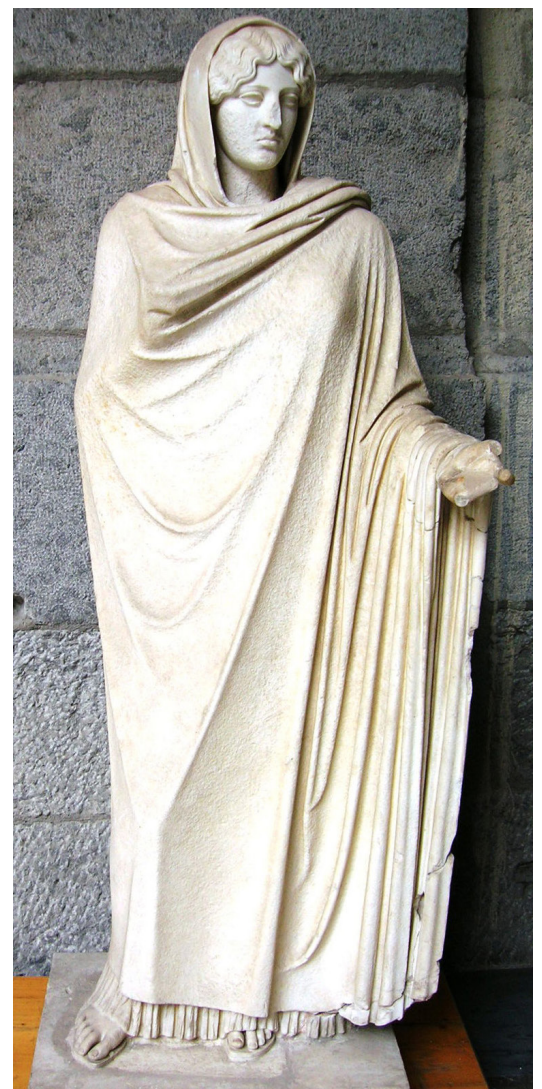

Figure 4. Aphrodite Sosandra.

8 Christine Mitchell Havelock, The Aphrodite of Knidos and Her Successors: A Historical Review of the Female Nude in Greek Art (Ann Arbor: University of Michigan, 1995), 103-4.

9 Natalie Boymel Kampen, "Gauging the Gender Gap," The Women's Review of Books 15, no. 5 (1998): 32, accessed Mar. 31, 2016, doi: 10.2307/4022863. There are quite a few inscriptions remaining from fourth century sanctuaries, which demonstrate that both families and women themselves made these dedications with their offerings. 
Buell 5

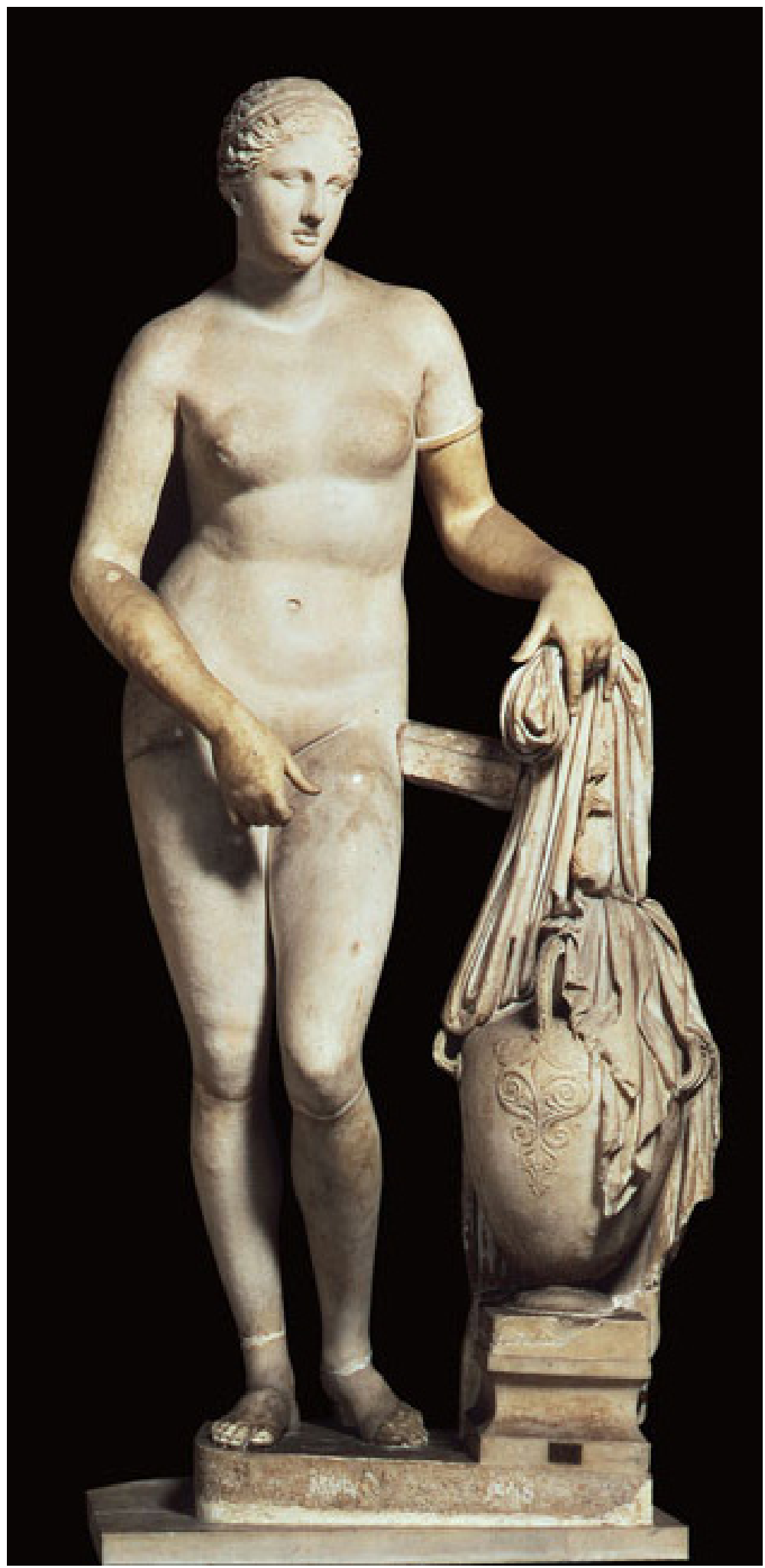

Figure 5. Aphrodite of Knidos (front view). 
Buell 6

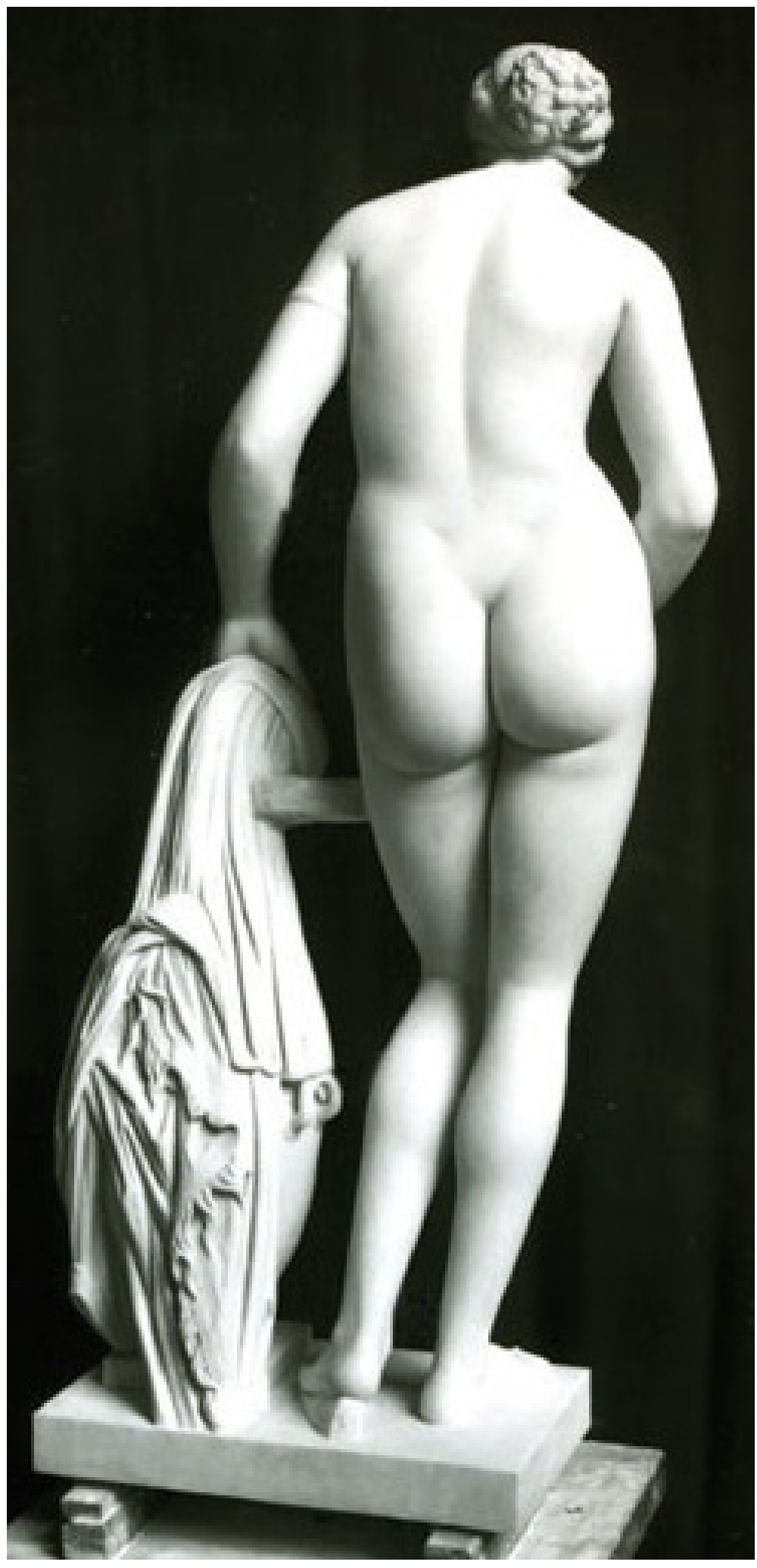

Figure 6. Aphrodite of Knidos (back view). 
Buell 7

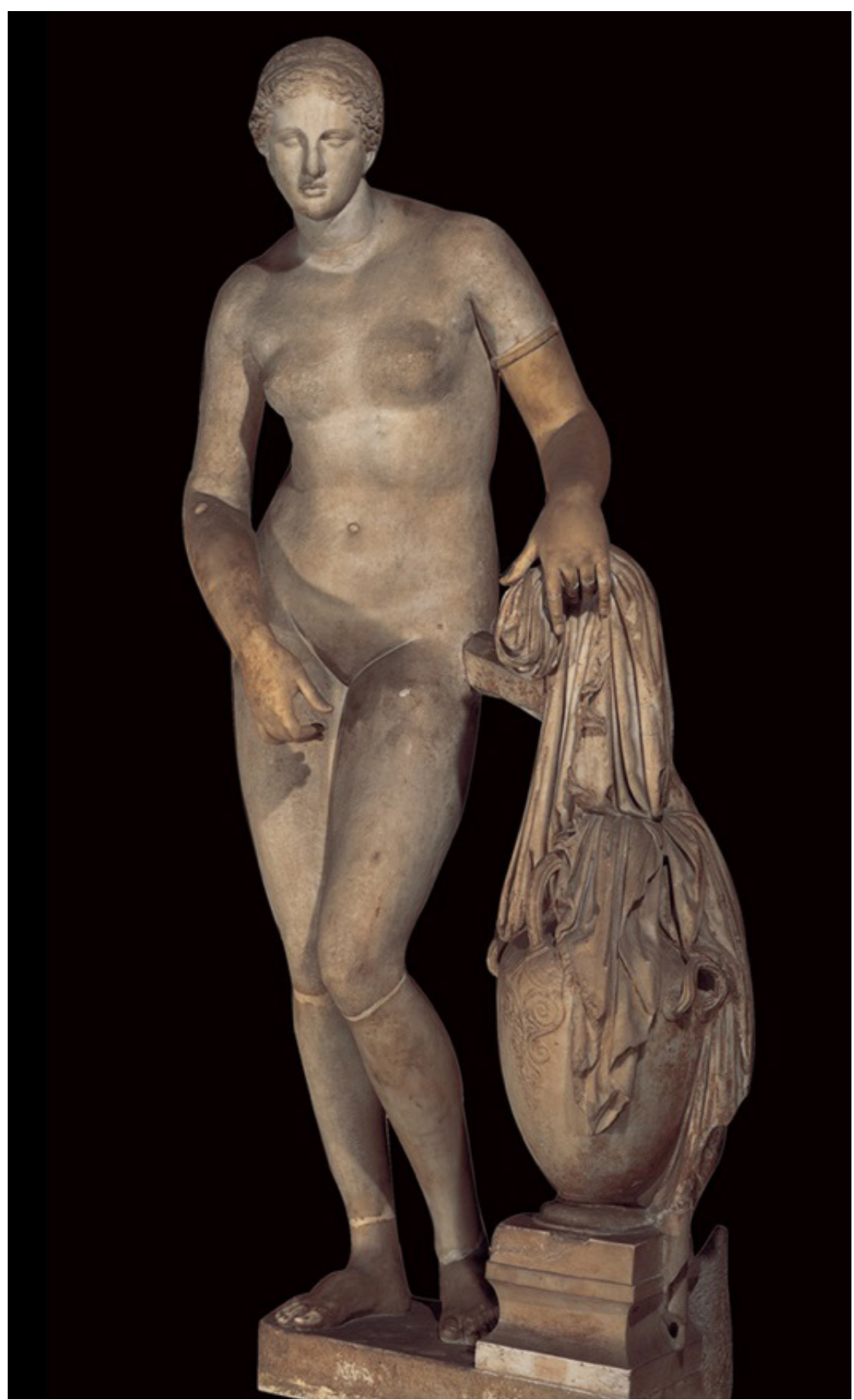

Figure 7. Aphrodite of Knidos (side view). 
The contrast between Praxiteles' creation and the previous clothed version is astounding. The Aphrodite Sosandra statue appears to be a stern, imposing figure shrouded protectively in her garments, keeping her sexuality safely hidden away. Whereas Praxiteles' interpretation of the goddess renders Aphrodite as a relaxed yet proud figure, her unclothed form both portraying and embracing her sexuality. This new and erotic image of the Goddess of Love in its refined and sensual nudity became the embodiment of love and sexuality. In that, a revolutionary idea, a bold expression, a new canon of depicting the female form, was born!

Very few records exist in the fourth century regarding the ideas women held about Aphrodite, but taking into consideration that women's lives were generally run by men, I speculate that Aphrodite must have been quite meaningful to women during that time..$^{10}$ Because of their restricted lives, women could do little to express their own femininity and sexuality, so the statue would have offered new profound significance. First, the goddess was an important figure in their religion, and women prayed to her for children and for favorable marriages. ${ }^{11}$ Second, a statue of the admired goddess in the nude gave recognition to the beauty, if not erotic nature, of women. Finally, the statue acted as a means where the female nude could be as idealized as the male nude.

This thesis examines the changing role of female statuary, particularly the depiction of the goddess Aphrodite and her function as religious and sexual symbol. Further, it reveals the Aphrodite of Knidos as a fourth century вCE trendsetter in the context of the changing roles of women, the move toward greater emotional content, and the bold interpretation of the female nude by the artist Praxiteles.

10 Natalie Boymel Kampen, "Epilogue: Gender and Desire," in Naked Truths: Women, Sexuality, and Gender in Classical Art and Archaeology, edited by Ann Olga Koloski-Ostrow, and Claire L. Lyons (London: Routledge, 1997), 270.

11 Kampen, "Gauging the Gender Gap," 32. The inscriptions in the sanctuaries also indicated prayers, such as these, that women made to Aphrodite. 


\section{Depictions of Women on Pottery}

While ancient Greek pottery did not commonly depict the female nude, when it did, women were often portrayed in a manner that provided pleasure to male viewers, with no regard whatsoever to a feminine audience. ${ }^{12}$ A nude image of a woman could also often be seen at the bottom of a wine cup called a kylix, which would be revealed as the contents were consumed (fig. 8). ${ }^{13}$ Topics of vase painting did begin to change prior to the fifth century все. ${ }^{14}$ With this change, pottery painting began to include the female audience with images such as female nudes bathing (fig. 9), and this kind of pottery was intended to be given as gifts for weddings. ${ }^{15}$ In the last part of the fifth century, the image of a clothed Aphrodite appeared on pottery intended for brides,${ }^{16}$ while cosmetic pottery used by women showed images that embraced their beauty, which "contributed to the [re-evaluation] of female sexuality."17

Pottery also became a popular gift not only for women, but for the bride and groom at a wedding celebration. The couple would frequently receive gifts of various types of pottery that depicted images of a sexual nature..$^{18}$ Depictions of ancient Greek art and mythological scenes on pottery often represented sexuality and fertility ${ }^{19}$ which could be seen as a means of the giver

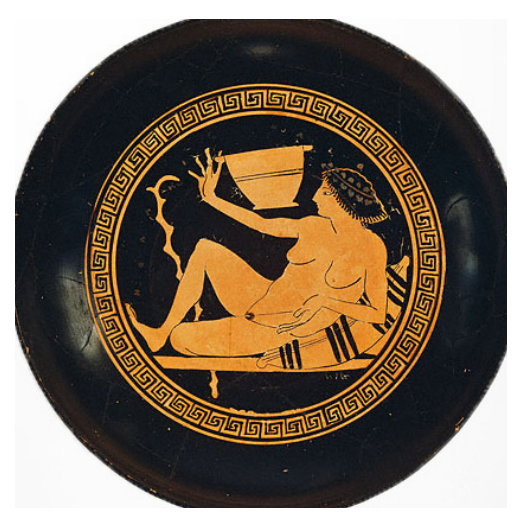

Figure 8. Woman Playing a Game expressing well-wishes to the couple in their efforts to reproduce.

12 Robert F. Sutton, Jr. "Pornography and Persuasion on Attic Pottery," in Pornography and Representation in Greece and Rome, edited by Amy Richlin (New York and Oxford: Oxford University Press, 1992), 9. Examples of this would include depictions of sexual intercourse, where the woman is in a submissive position and the man is in a dominant role.

13 Ibid., 22.

14 Ibid., 4.

15 Sutton, 22.

16 Ibid., 30.

17 Ibid., 33.

18 Peter Webb, "Erotic Art," Grove Art Online, Oxford Art Online (Oxford University Press), last modified May 28, 2015, accessed Mar. 4, 2016, http://www.oxfordartonline.com.proxy.lib.pdx.edu/subscriber/. article/grove/art/T026580.

19 Ibid. 
During the Hellenistic Period, Alexander the Great's conquests brought in "new ideologies and views," and this initiated transformations regarding the role of women

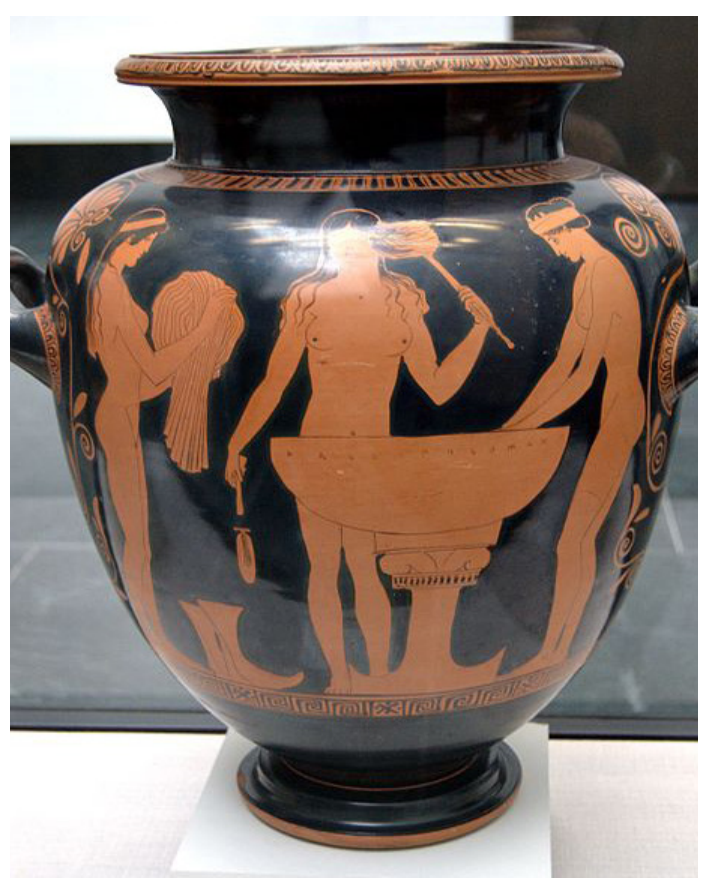

Figure 9. Three Women Bathing. in society. ${ }^{20}$ Following along the path of Alexander's own mother, Olympias-who would be responsible for the Royal Court during the absence of her son-upper-class women gained power in politics as well as the state. ${ }^{21}$ Eventually, women were able to choose whom they could marry, and they could earn an education. ${ }^{22}$ Also, they were more frequently represented in art in a more positive manner, whereby they no longer were shown as servants or prostitutes. While the exact date of Praxiteles' statue is not known, we can theorize for a moment that its creation occurred in 330 вСЕ. The role of women was changing, and this period when women's power and education opportunities were rising would have been an ideal time to make an outrageous statue, a powerful nude female figure, as the idea of change was already in the minds of the Greeks. Perhaps women's new roles and growing power translated into art. At the time that Praxiteles created the statue, depictions of female nudes started to increase. ${ }^{23}$

20 Jenni Irving, "Greek Women Classical to Hellenistic: A Brief Discussion of Changing Factor," Graeco Muse, 2013 accessed Apr. 15, 2016, https://graecomuse.wordpress.com/2013/01/11/greek-womenclassical-to-hellenistic-a-brief-discussion-of-changing-factors. New perspectives and ideas started occurring in Greece because of Alexander the Great's conquests. These new ideas also allowed high class women to hold political, legal, and economic power, to own property, and to control their own finances.

21 Ibid.

22 Ibid.

23 Sutton, "Pornography and Persuasion," 21. 


\section{The History of Aphrodite of Knidos}

Buell 11

While Praxiteles frequently depicted Aphrodite, other goddesses, and even mortals in his many sculptures ${ }^{24}$ the Aphrodite of Knidos is his most well-known work. ${ }^{25}$ Created sometime between 360 and 330 все, Praxiteles likely used his mistress and courtesan, Phryne, as the model. ${ }^{26}$ Additionally, Praxiteles made two copies of Aphrodite, one clothed in drapery and the other nude, offering the town of Kos a choice between the two. ${ }^{27}$ Kos chose the clothed version, which enabled Knidos to purchase the nude Aphrodite, earning the city great fame for it. ${ }^{28}$

Literature around the time of the statue's creation has not come down to us. ${ }^{29}$ The earliest surviving accounts come from Pliny the Elder and Lucian, nearly four hundred years after the Knidian was made. ${ }^{30}$ Pliny was a Roman scholar who collected information and compiled it all into an encyclopedia of books called Natural History, which was finished in $77 \mathrm{CE} .{ }^{31}$ Lucian, a rhetorician born around $125 \mathrm{CE}$ in Samosata, which was on the eastern side of the Roman Empire, wrote his accounts in Greek. ${ }^{32}$ It is likely that Pliny never saw the statue in person, ${ }^{33}$ however, he described it as a masterpiece, claiming people sailed from various parts of the world to see it. ${ }^{34}$ Around 393-394 все, the statue was removed from Knidos and housed in the palace of Lausus

24 Havelock, The Aphrodite of Knidos, 41.

25 Ibid., 48.

26 Ibid., 9.

27 Ibid., 10.

28 Ibid.

29 Ibid., 55.

30 Ibid.

31 Francesco De Angelis, "Pliny the Elder and the Identity of Roman Art" RES: Anthropology and Aesthetics 53/54 (2008), 79-92 accessed Apr. 11, 2016, http://www.jstor.org.proxy.lib.pdx.edu/stable/25608810. Book 36 of Pliny's Natural History comments on the Aphrodite of Knidos specifically.

32 Daniel Richter, "Lives and Afterlives of Lucian of Samosata," Arion: A Journal of Humanities and the Classics 13, no. 1 (2005), 75-100, accessed Apr. 11, 2016, http://www.jstor.org.proxy.lib.pdx.edu/ stable/29737246. Not much is actually known about Lucian's personal life because he recorded very little about it, so he might not actually have been born in Samosata.

33 Amy Claire Smith and Sadie Pickup, Brill's companion to Aphrodite (Leiden: Brill, 2010), 254. It is very possible Pliny got his description of the statue from Mucianus, a Syrian governor, who traveled extensively while he was in exile.

34 Havelock, 9-10. 
in Constantinople, where later it was sadly destroyed in a fire in 476 CE. ${ }^{35}$ Based on Lucian's accounts in Amores, he saw the Knidian Aphrodite first hand before its unfortunate destruction. ${ }^{36}$ However, other copies of the Knidian had been made, and she was even shown on coins (fig. 10). ${ }^{37}$

A majority of the copies agree that the Knidian was in a contrapposto stance, and that her head was facing to her left. ${ }^{38}$ The details that remain unclear, however, include the degree to which her head was tilted, which hand she held over her pubis, how the arm that held the drapery was positioned, whether she was wearing any jewelry, and if she

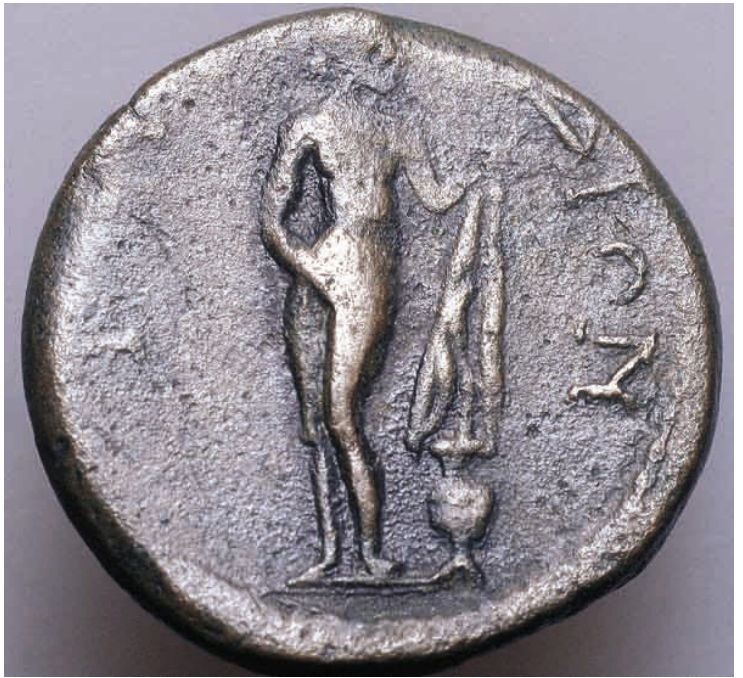

Figure 10. Roman coin depicting the Aphrodite of Knidos. was slender or voluptuous. ${ }^{39}$ Her facial expression is also a mystery, though Lucian describes Aphrodite as having "a look of proud contempt and a slight smile which just reveals her teeth." ${ }^{40}$

A common practice in Greek statuary was for the statues to be painted, which both Pliny and Lucian ascribe to the Knidian. In that case, Praxiteles' statue most likely would have been painted by Nikias, an artist he admired. ${ }^{41}$ Prime components to be painted would have been her eyes, hair, lips, cheeks, jewelry, and a light color might

35 Corso Antonio, "Aphrodite of Cnidus," Encyclopaedia of the Hellenic World, Asia Minor, (2002), sec. 8.3., accessed Apr. 22 2016, http://asiaminor.ehw.gr/forms/fLemmaBodyExtended. aspx?lemmaID $=3876$.

36 Lucian (attributed), Amores, trans. A.M. Harmon (Loeb edition), accessed Apr. 18, 2016, http:// www.well.com/user/aquarius/lucian-amores.htm. Lucian frequently makes references in first-person plural, such as "we decided to see all of the goddess," which indicated he saw it himself.

37 Ibid., 9.

38 Ibid., 11

39 Ibid., 12

40 Ibid., 10-11

41 Havelock, The Aphrodite of Knidos, 13-14. For this reason Praxiteles most likely would have requested Nikias to paint his sculpture. 
Buell 13

have been added to her skin. ${ }^{42}$ Also, the hydria, the vessel seen at her side and containing water for a bath (fig. 11), would have been painted, along with the drapery cascading across the vase.

The town of Knidos, located in what is now Tekir, Turkey, was situated at the point of a thin peninsula (fig. 12), and Aphrodite's sanctuary was positioned on a hill that had a view of town and the sea. ${ }^{43} \mathrm{~A}$ round temple, or tholos, is commonly associated with Aphrodite, and this could imply that the Knidian was housed in one. ${ }^{44}$ Pliny's accounts support this idea as he writes about the statue in an open and round structure that enabled viewing from all sides..$^{45} \mathrm{~A}$ replica of the round temple was created by a Roman emperor to hold a copy of the Knidian, which also reinforces the idea that she was housed in a tholos. ${ }^{46}$

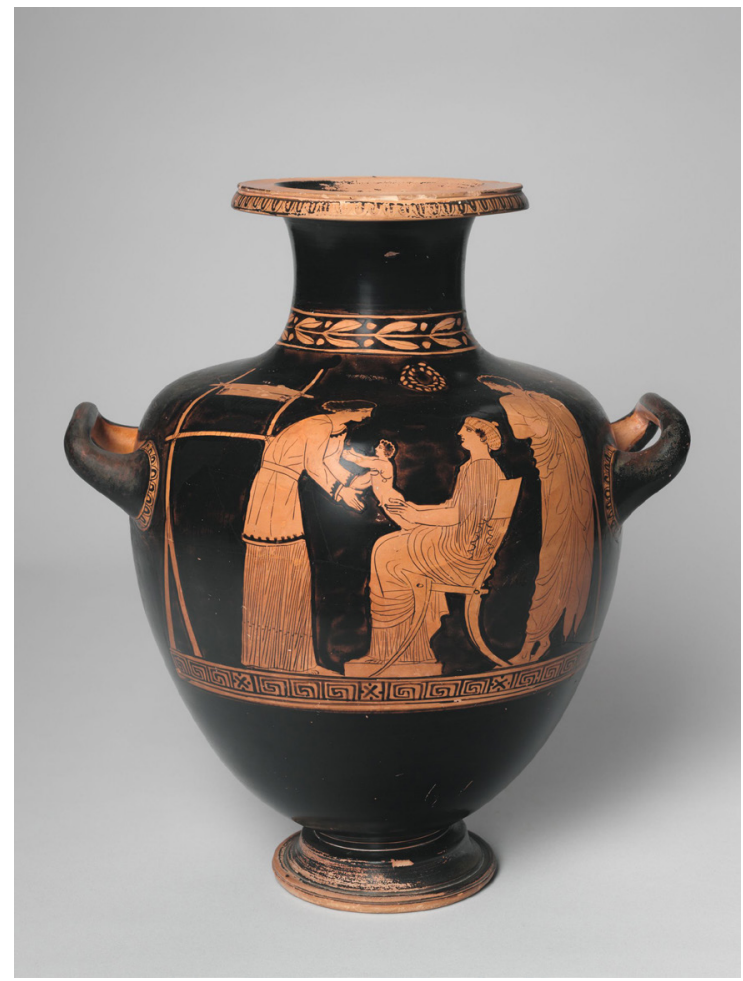

Figure 11. Hydria (water jar): Family Scene.

42 Ibid., 14.

43 Havelock, 58.

44 Iris Cornelia Love, “A Preliminary Report of the Excavations at Knidos, 1969," American Journal of Archaeology 74, no. 2 (1970): 154, accessed Oct. 22, 2015, doi: 10.2307/503205.

45 Havelock, 60.

46 Ibid. 


\section{The Nude Statue}

No respectable woman — let alone a goddess — had ever before been depicted nude as a statue. ${ }^{47}$ As stated, nude females were shown in pottery painting, and usually these subjects were of low social status. This included depictions of prostitutes and victims of violence, which consisted of captured and abducted women of conquered lands (fig. 13), or even rape scenes (fig. 14). ${ }^{48}$

In his nude statue of the goddess, depicted as an enticing symbol of sexuality, Praxiteles

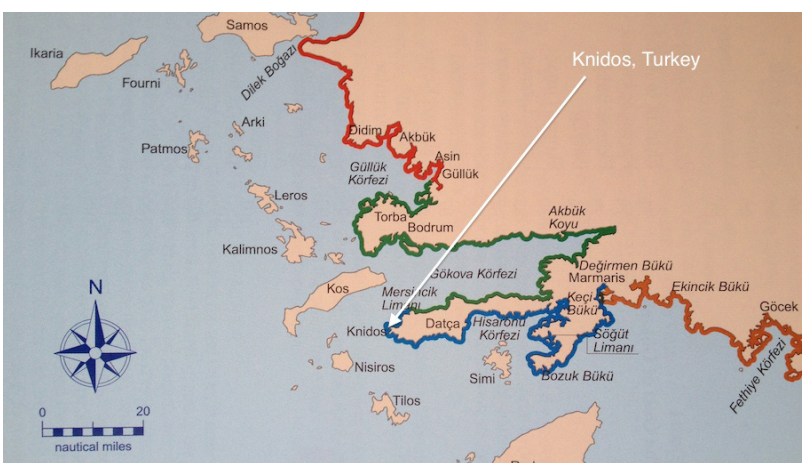

Figure 12. Knidos, Turkey. made an incredible breakthrough leaving the general context of female nudity in art behind. This makes the fourth century artist a Caravaggio of his time. Just like the 17 th century artist who created bold and emotionally charged content in his work, the viewers of the nude statue by Praxiteles were certainly divided in opinion about this outlandish work. ${ }^{49}$ The town of Kos wanted nothing to do with the statue, whereas the town of Knidos loved it. Praxiteles' depiction of a nude goddess was outrageous, but he contextualized her nudity in placing the drapery and hydria next to her, indicating her imminent bath.

Water had great significance in ancient Greece for its purifying qualities and for its representation of renewal. ${ }^{50}$ Illustrated in the statue's pose next to the hydria,

\footnotetext{
47 Ibid., 9.

48 Bahrani, "The Hellenization of Ishtar," 4.

49 Sharon Gregory, "Caravaggio and Vasari's 'Lives," " Artibus et Historiae 32, no. 64 (2011): 168, accessed Apr. 13, 2016, http://www.jstor.org.proxy.lib.pdx.edu/stable/41479760. Caravaggio was born in the late 16th century, and as an artist he painted quite differently from others, which created a lot of controversy. At the time, it was the norm to paint idealized scenes, but Caravaggio painted from life. He painted what he saw in front of him, flaws and all. Some people viewed Caravaggio's art as cheap, imitative works that had no real substance. Others greatly admired his works for their high drama.
}

50 Havelock, 23. 


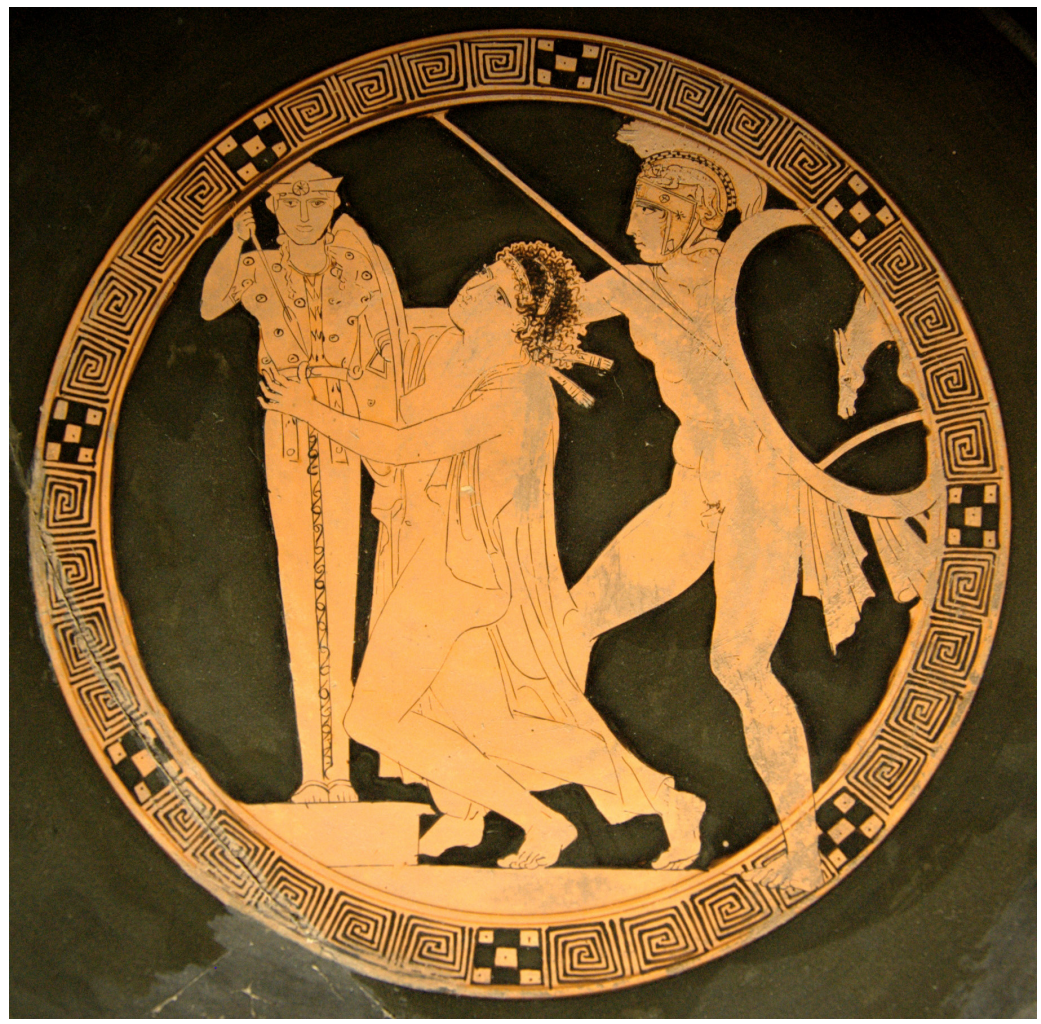

Figure 13. Kylix depicting Ajax the Lesser Raping Cassandra.

Figure 14. Kylix depicting Greek scene of erotisicm and violence.

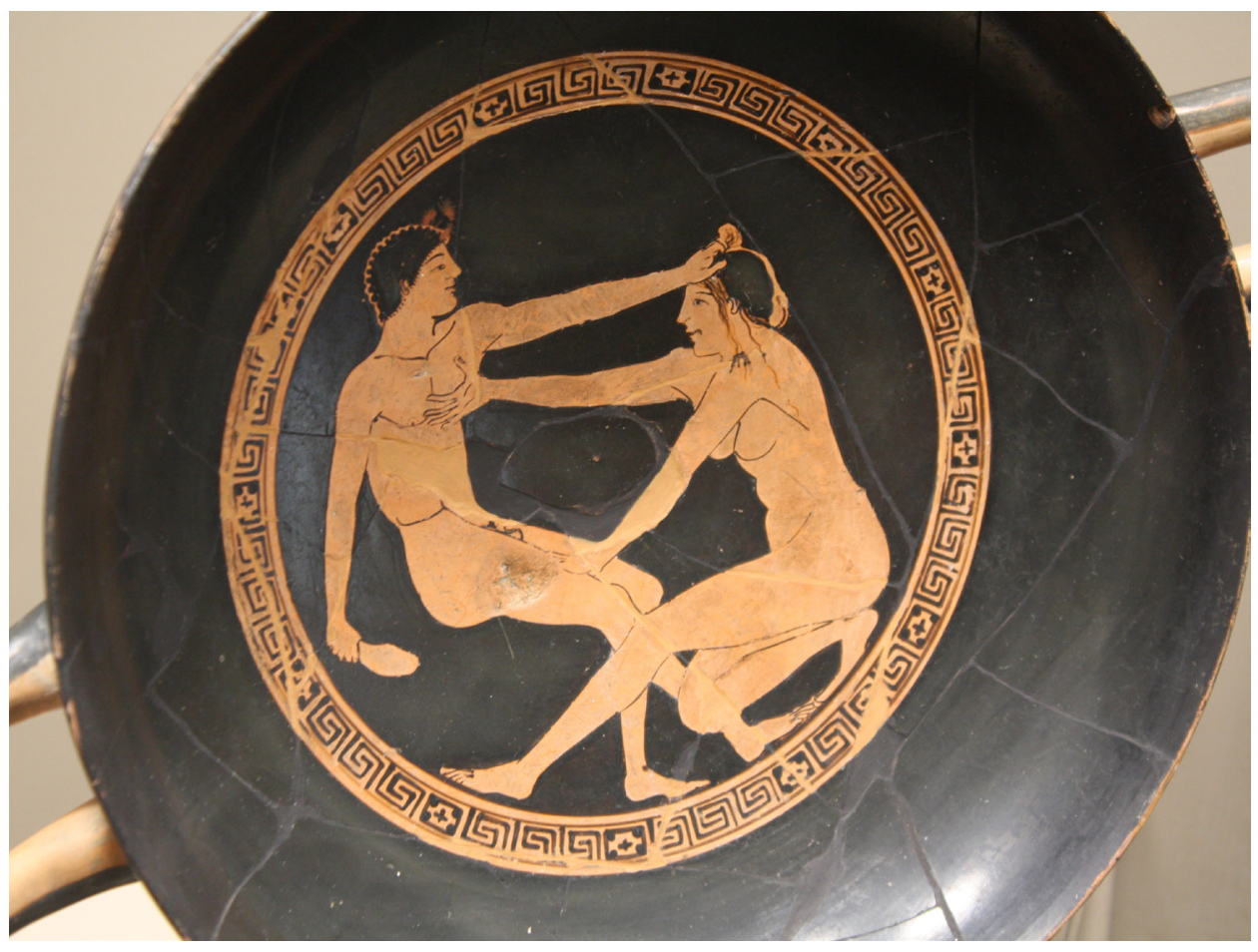


Buell 16

the goddess commonly took baths, which would have been renewing and purifying to her. ${ }^{51}$ Her frequent bathing relates back to her divine birth at sea, and also explains her

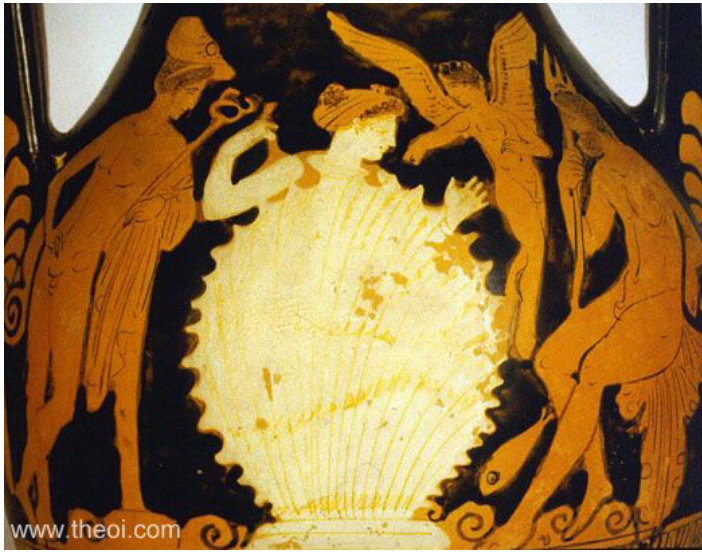

Fig. 15. The Birth of Aphrodite. affinity to water. ${ }^{52}$

The story behind Aphrodite's

birth also gave Praxiteles additional context for depicting the goddess nude (fig. 15). ${ }^{53}$ Her mother, Gaia, conspired with Cronus to castrate her abusive husband Uranus. After this deed was done, Aphrodite was born of the sea

foam created by Uranus' severed genitals. Born as an adult, she of course was naked and in that completely natural state - which was such an integral part of her essence - she likely would have had no shame being nude. Combined with her birth in the sea, and with her parents representing natural elements, ${ }^{54}$ being seen thus in the nude was a perfect embodiment of Aphrodite, her femininity, and her sexuality.

The gesture of her hand covering her pubis has been termed "the pudica pose," or a pose of modesty ${ }^{55}$ However, since Aphrodite was the embodiment of love and sexuality, can we really say that the aim of Praxiteles' bold work was to depict this love goddess as modest? While some scholars agree that the placement of the hand was a modest display, others believe that this pose was instead incredibly intentional. ${ }^{56}$ Her hand is not covering up her pubis in modesty, instead, her hand is idly placed while the figure of Aphrodite casually sets aside her drapery. She is not even thinking about her hand, but we, as the viewer, certainly are.

51 Ibid., 36.

52 Londyn Lamar, “Aphrodite and her Famous Nudity," Heritage Daily, May 28, 2013, accessed Nov. 22, 2015, http://www.heritagedaily.com/2013/05/aphrodite-and-her-famous-nudity/89666.

53 Ibid.

54 Ibid.

55 Barrow, "From Praxiteles to De Chirico," 350.

56 Ibid. 


\section{The Sexuality of Aphrodite}

As stated, women's lives were strictly regulated in ancient Greece, though that was starting to change in the Hellenistic Period with the conquests of Alexander the Great. Still, female sexuality was fiercely controlled, and to the Greeks, premarital sex was a great threat to the family. A law stated that if a young woman had sex before she was married, her father would have the option of disowning her and sending her away into slavery. ${ }^{57}$ Even so, interest in depicting the female form as a more sensuous figure was starting to increase.

Earlier in sculpture, the female form was depicted according to norms established by the societal role of women. At the end of the fifth century вСЕ, a new style of sculpture was born that gives the apparent look of a wet garment. This new style allowed the female form to be seen underneath the drapery, as if her clothing was wet and clinging to her (fig. 16), ${ }^{58}$ earning it the name "wet drapery style." Sculptors thus showed the sensuality and sexuality of the female form without breaking restrictions of showing the naked female body. The so-called "wet drapery style" was a vital precursor to Praxiteles depicting Aphrodite in the nude, and I speculate that it was a time where artists were exploring and embracing the idea of showing the female form more sensuously.

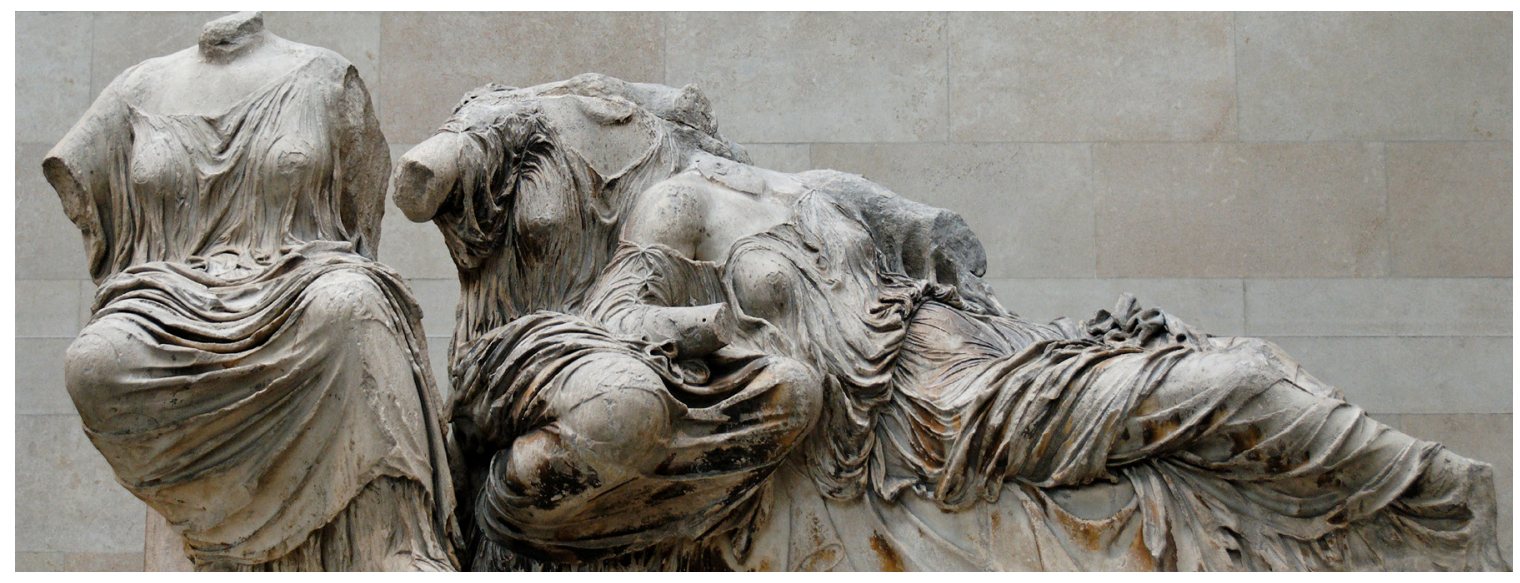

Figure 16. Hestia, Dione, and Aphrodite, from Parthenon East Pediment.

57 Sissa, "Maidenhood without Maidenhead," 346.

58 Salomon, "Making a World of Difference," 203. 
When Praxiteles created his statue in the mid-fourth century, he showed that women as well as men could be idealized. ${ }^{59}$ Thus he elevated the representation of nude women in the arts. Aphrodite represents the power of a goddess that embraces her own sexuality, which contributed to her becoming the subject of the first monumental nude female. ${ }^{60}$

Greek terms highlight the Knidian's sexuality. The first, aidoia, stands for the "genitals of either sex," and the second, aidos, means "reverence, awe, or respect" but also the "experience of sight and being seen." ${ }^{\text {"1 }}$ Aphrodite is utterly exposed in her nudity, her aidoia (genitals) barely concealed behind her enigmatically placed hand, and she is unperturbed by her lack of garments. In her nakedness, and as a goddess, she commands aidos (reverence, awe, and respect) entirely. She tempts people to experience the sight of her sexuality and femininity. The idea that her hand is covering herself in shame is far-fetched; in fact, her hand does not do much to obscure her pubis at all. The hand, rather, is a sort of tease. Viewers tend to want to see what is being playfully denied. ${ }^{62}$

Andrew Stewart, professor of Ancient Mediterranean Art, states that the Knidian was “aware" of the viewer's presence, shown by her hand covering her pubis, in what he interpreted to be shame, and her outward looking gaze, which makes the viewer a "peeping Tom.. ${ }^{93}$ Is this depiction of the Goddess of Love really embarrassed that someone caught her at her bath, or was the sculpture's pose meant to express her innate sexuality? Brunilde Sismondo Ridgway, a specialist in ancient Greek sculpture, states that the Knidian looks like she simply got lost in thought and that she was shown "as unconscious and glorious" as other depictions of nude males. ${ }^{64}$ As the Goddess of Love, her femininity and sexuality was an integral part of her power as a goddess and a woman, which she embraced fully in her nudity.

59 Lamar.

60 Ibid.

61 Havelock, 10-11.

62 Salomon, 211.

63 Andrew Stewart, Greek Sculpture: An Exploration (New Haven and London: Yale University Press, 1990), 178.

64 Brunilde Sismondo Ridgway, Fourth-Century Styles in Greek Sculpture (Madison: University of Wisconsin Press, 1997), 263. 
Aphrodite's sexuality can also be seen when considering the woman said to have been the model for Praxiteles: Phryne. She was a wealthy courtesan, and had many lovers, including Praxiteles himself. ${ }^{65}$ In ancient Greece, as in any culture, love was for sale, and two different types of prostitutes with various degrees of status existed. Hetairai, or courtesans, such as Phryne held high status, and were often quite educated. ${ }^{66}$ The role of these women went beyond just selling their bodies; they also engaged in various social activities and as the companions of their patron. ${ }^{67}$ Hetairai were more independent than other Greek women because of their relatively high status and the wealth they gained through their patrons. ${ }^{68}$ Young girls could not be considered hetairai, nor could lower class women or slaves, and they instead were pallakai, or concubines. ${ }^{69}$ They would sell themselves to many clients rather than having a few patrons, and were generally not educated.$^{70}$ While definitely not a prostitute, the Goddess of Love does, however, share some common traits with Phryne or hetairai. One example was that they had many lovers. Aphrodite, as well as Phryne, also had more freedom than other women. In Phryne's case, she was able to attend events that were normally only accessible to men. ${ }^{71}$ As a deity, Aphrodite could clearly go wherever she pleased and love whomever she desired. Perhaps Praxiteles relied on the role of Phryne to create additional meaning in his revolutionary and dramatic depiction of a nude goddess?

We should also consider that Aphrodite's nudity may go beyond her sexual nature and also refer to fertility and the reproductive aspect of women..$^{72}$ According to Pliny's accounts, the town of Kos chose the clothed version of Aphrodite because they thought

65 Havelock, 47.

66 Lee, Body, Dress, and Identity, 48. Hetairai could be educated in arts such as music and poetry.

67 Jess Miner, "Courtesan, Concubine, Whore: Apollodorus' Deliberate Use of Terms for Prostitutes," The American Journal of Philology 124, no. 1 (2003): 22, accessed Mar. 12, 2016, http://www. jstor.org.proxy.lib.pdx.edu/stable/1561932.

68 Lee, 48.

69 Miner, "Courtesan, Concubine, Whore," 23.

70 Ibid., 24.

71 Havelock, 47.

72 Barrow, 351. 
Buell 20

she was "chaste." 73 However, Aphrodite does not represent chastity as the Goddess of Love, and likely it was convention that made the town of Kos opt for the clothed figure. This would leave the nude and "new" model to be received by the Knidians, surprisingly bringing fame and fortune to the town.

Lucian's accounts say that the Knidian's sexuality was so powerful that heteroand homosexual men alike found themselves desiring her. ${ }^{74}$ No one could deny the Goddess of Love! Pliny wrote about a man who found the Knidian so alluring, that he hid inside the temple so at night he could make love to the statue, evidenced by stains left behind.$^{75}$ Another reference attributed to Lucian describes two young men-one said to be a heterosexual, and the other a homosexual—-who visited the statue. ${ }^{76}$ They also noticed the stains left behind on the back of Aphrodite's thighs. ${ }^{77}$ Apparently aroused by this, one of the boys planned to hide out and make love to the statue. ${ }^{78}$

As a goddess, Aphrodite was an incredibly powerful being. She elicited sexual craving in mortals and gods, though those cravings tended to come with great repercussions for everyone involved..$^{79}$ Even for the goddess herself. A compelling example of both positive and negative affects of her power is the tale of Helen of Troy. From her manipulation of lust to be judged as the most beautiful goddess, and furthered by Paris' lust for Helen, she brought about the Trojan War. Even though Helen was already married, Aphrodite's power ripped apart the marriage of Helen and Menelaus. This shows that Aphrodite was not shy with her power.

When Aphrodite herself suffered as a result of her own manipulations, it was

73 Michael Squire, The Art of the Body: Antiquity and its Legacy, (Oxford: University Press, 2011), 91.

74 Ibid., 98.

75 Barrow, 351.

76 Ibid. Barrow believes that the Erotes, which is attributed to Lucian, is actually from a later point and another author.

77 Ibid.

78 Ibid.

79 Monica Silveira Cyrino, “'Shame, Danger and Desire': Aphrodite's Power in the Fifth Homeric Hymn," Rocky Mountain Review of Language and Literature 47, no. 4 (1993): 219, accessed Mar. 6, 2016, http://www.jstor.org/stable/1348308. 
Buell 21

because she used her powers against Zeus, king of the gods. Even though Zeus was married to Hera, he was constantly having affairs with mortal women. In an effort to gain her husband's affections, Hera, with the help of Aphrodite, seduced her own husband. Furious, Zeus forced Aphrodite to lust after a mere mortal in punishment. ${ }^{80}$

Previously, Lucian described the Aphrodite of Knidos as proud and contemptuous, bearing a slight smile on her face, obviously someone not ashamed of nudity. As the Goddess of Love, Aphrodite relishes her sexuality and her femininity, and this trait is distinctly embodied within Praxiteles' statue.

\section{Aphrodite's Inspiration for Other Works}

The Knidian Aphrodite has asserted her artistic influence and induced inspiration for centuries. ${ }^{81}$ Whether Praxiteles intended to create shock and drama, or wanted to celebrate the female form in new ways, the statue's impact cannot be denied. Hellenism at large produced dramatic and emotional works of art, though none more than the Knidian. Many artists admired Praxiteles' statue, and began to immortalize the sensual goddess in their own creations. Numerous similarities can be seen between the Aphrodite of Knidos and other works of art. ${ }^{82}$

For example, with the statue grouping of Aphrodite, Pan, and Eros (fig. 17), we see a playfully sensuous work. Aphrodite is on the left side of the scene, holding a sandal in her right hand as if she is going to mischievously strike Pan with it. Pan is on the right side of the scene, and is grasping her left arm, smiling flirtatiously. Eros is flying between the two, clearly encouraging the romance. Aphrodite's hand is over her pubis in the "pudica pose," a form that had never been seen until Praxiteles created it. Therefore, we can speculate that the artist had seen, and been influenced by, Praxiteles' sculpture.

80 Ibid., 222.

81 Salomon, 197.

82 Ibid., 199. 
Additionally, Pan seems intent on pulling Aphrodite's hand away from her pubis, taunting us as the viewer with the possibility of her complete exposure. This brings back to mind the idea of the Knidian Aphrodite's hand held teasingly over her pubis. Certainly this artist had an interest to continue on with the form of a sensual, teasing pose that Praxiteles so masterfully created. ${ }^{83}$

The Capitoline (fig. 18) and Medici Aphrodites (fig. 19) are further examples of artists copying the creative pose that Praxiteles devised. Both of these statues have their arms

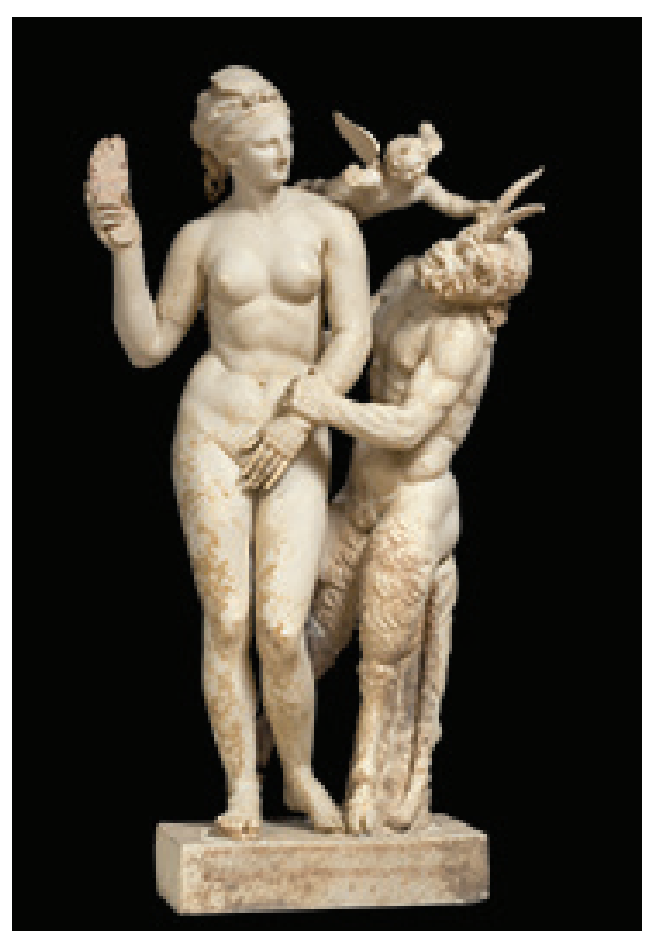

Figure 17. Aphrodite, Pan, and Eros. held up to their bodies in a delicate, sensuous manner that emphasizes their feminine forms ${ }^{84}$ Their arms also serve to artfully draw the viewer's gaze in a manner that highlights their sexuality and sensuality in a coy, teasing way. The captivating spirit of the Aphrodite of Knidos lives on in these depictions of the Goddess of Love, as they continue to uphold Praxiteles" "pioneering genius." 85

During the Hellenistic period and the conquest of foreign lands, Greek culture was exposed to new ideas. As stated, the role of women began to change, and trade with the Near East during the fourth and third centuries BCE influenced artistic expression. ${ }^{86}$ Art from Mesopotamia exaggerated the female breasts and pubis, either by enlarging these parts or by the gestures of the figure drawing attention to them with her hands (fig. 20). ${ }^{87}$

\footnotetext{
83 Havelock, 56.

84 Ibid., 70.

85 Ibid., 79.

86 Bahrani, 4.

87 Ibid., 8.
} 


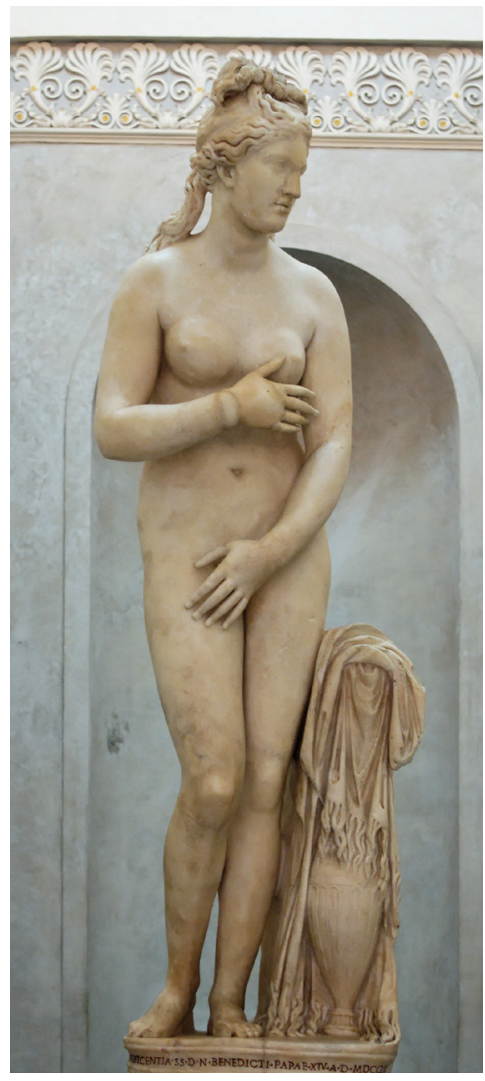

Figure 18. Capitoline Aphrodite.
Statuary of women directed the viewer's gaze to the body's most sexual aspects, and emphasized eroticism in the female form. Although the Knidian may not be as overtly sexual as a statue from the Near East, she most certainly directs the viewer's gaze by her elegantly and conveniently placed hand. This "eye-leading” approach is seen in the later works of the Capitoline and Medici Aphrodites, which likely simulate the Near Eastern approach more than the statue by Praxiteles.

\section{Conclusion}

While attitudes toward women depicted in art had been slowly changing prior to the fifth century, the male nude had been the exemplary subject of art for centuries. His was the ideal form, to be admired and rendered beautifully into a work of art; however, since the mid-fourth century when Praxiteles created the Aphrodite of Knidos, the male form had to increasingly share the spotlight with his female counterpart. The Greeks obviously did not seem to mind, for depictions of the nude female grew in number.

Praxiteles created his Aphrodite of Knidos as a symbol of female sexuality, one without demur or shame. As the Goddess of Love and as a powerful woman she had little cause for embarrassment, and in that Praxiteles boldly chose to depict her in the nude. The figure indeed embodies Aphrodite's sensual and sexual nature, and displays a new rendition of the female form. Sculpture of the fifth century appears as a perfect precursor wherein the body was sensually displayed underneath the drapery. The so-called "wet drapery style," seen, for example, in the Nike adjusting her sandal relief panel (fig. 21), seems to experiment with the sensuous aspects of the female body. The next logical step 
Buell 24

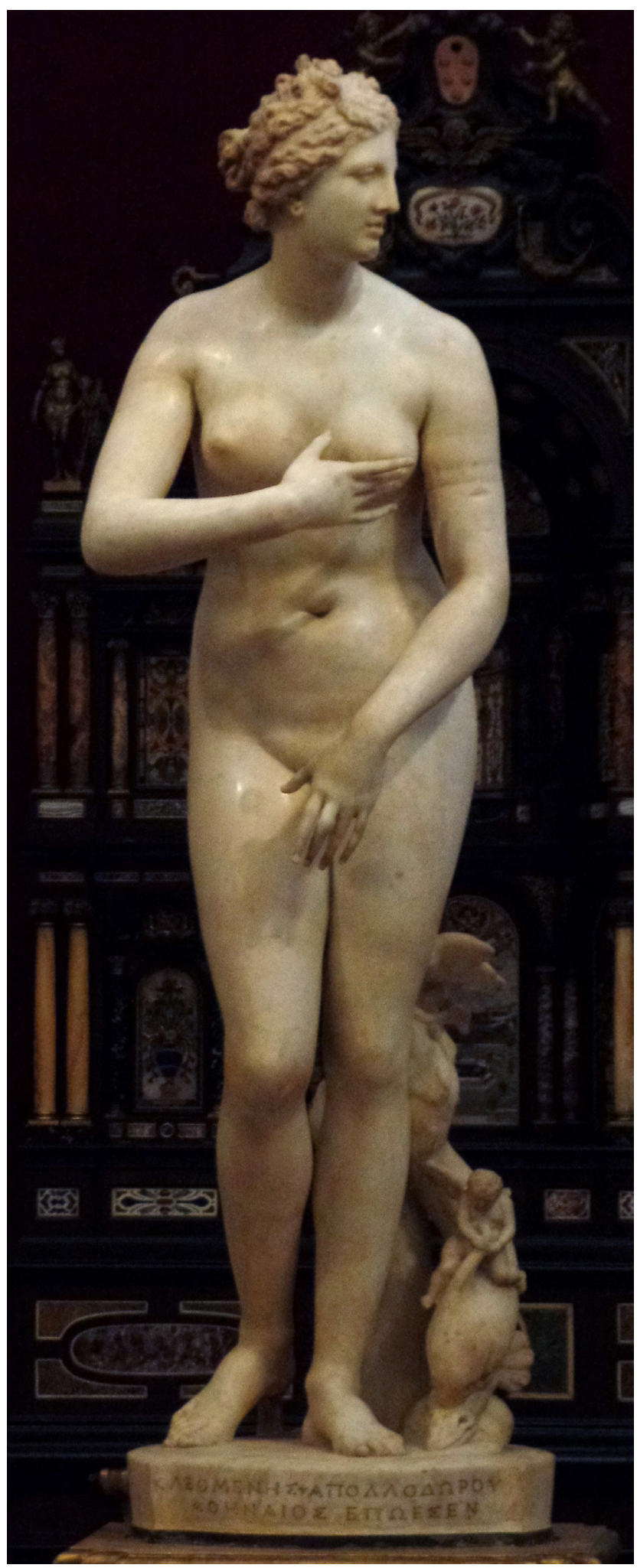

Fig. 19. Medici Aphrodite. 
was to remove the drapery altogether and indeed, Praxiteles was the one to take it off.

During the Hellenistic Period, the portrayal of the human form was redefined by artistic expression. Sculptors played with ideas concerning emotion, sexuality, and sensuality, with both the female and male form alike. Clearly eroticism in art was on the rise. The male figure, depicted in the nude for centuries, takes on sensuous and sexually enticing aspects, as is seen in the Barberini Faun (fig. 22), where the viewer is placed within that voyeuristic position that allows her or him to enter into a dialogue regarding sensuality. The female form follows, perhaps more timidly, but as we can see in the Knidian Aphrodite, viewers are invited to claim a new perspective of the Goddess. The wonder of the revolutionary statue inspired

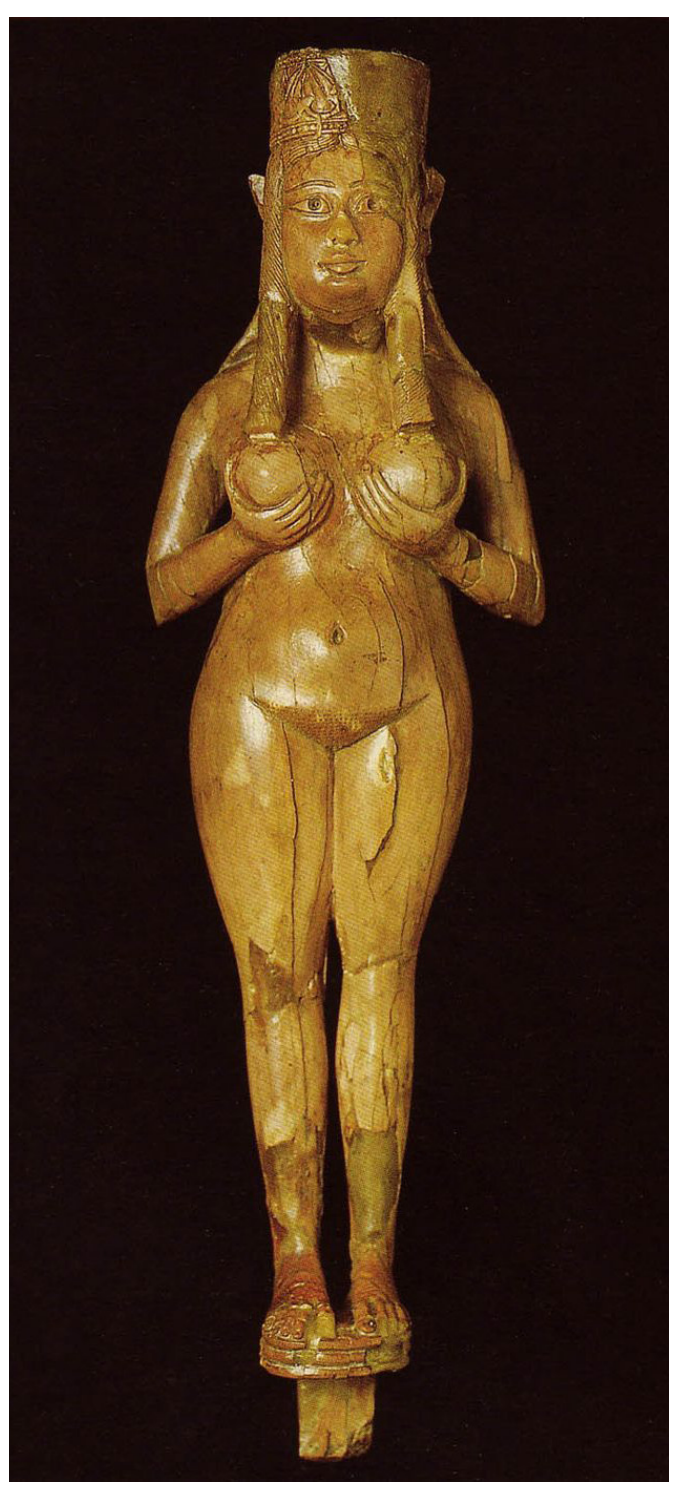

Figure 20. Female Figurine. love and admiration. This all began with Praxiteles creating a statue of the Goddess of Love. The enjoyment experienced by countless viewers inspired within them a need for more bold expressions, which attests to the Aphrodite of Knidos' role as a trendsetter.

Perhaps new ideas of artistic styles brought from the East, the changing role of women in the Greek world, and a bold-faced artist's outlook toward eroticism and sensuality lay behind the statue's final execution. Most certainly, the Aphrodite of Knidos embodies an innovation in sculpture of the Greek world, for nothing like the statue had ever been made before. As a perfect subject matter, Praxiteles uses the 
Buell 26

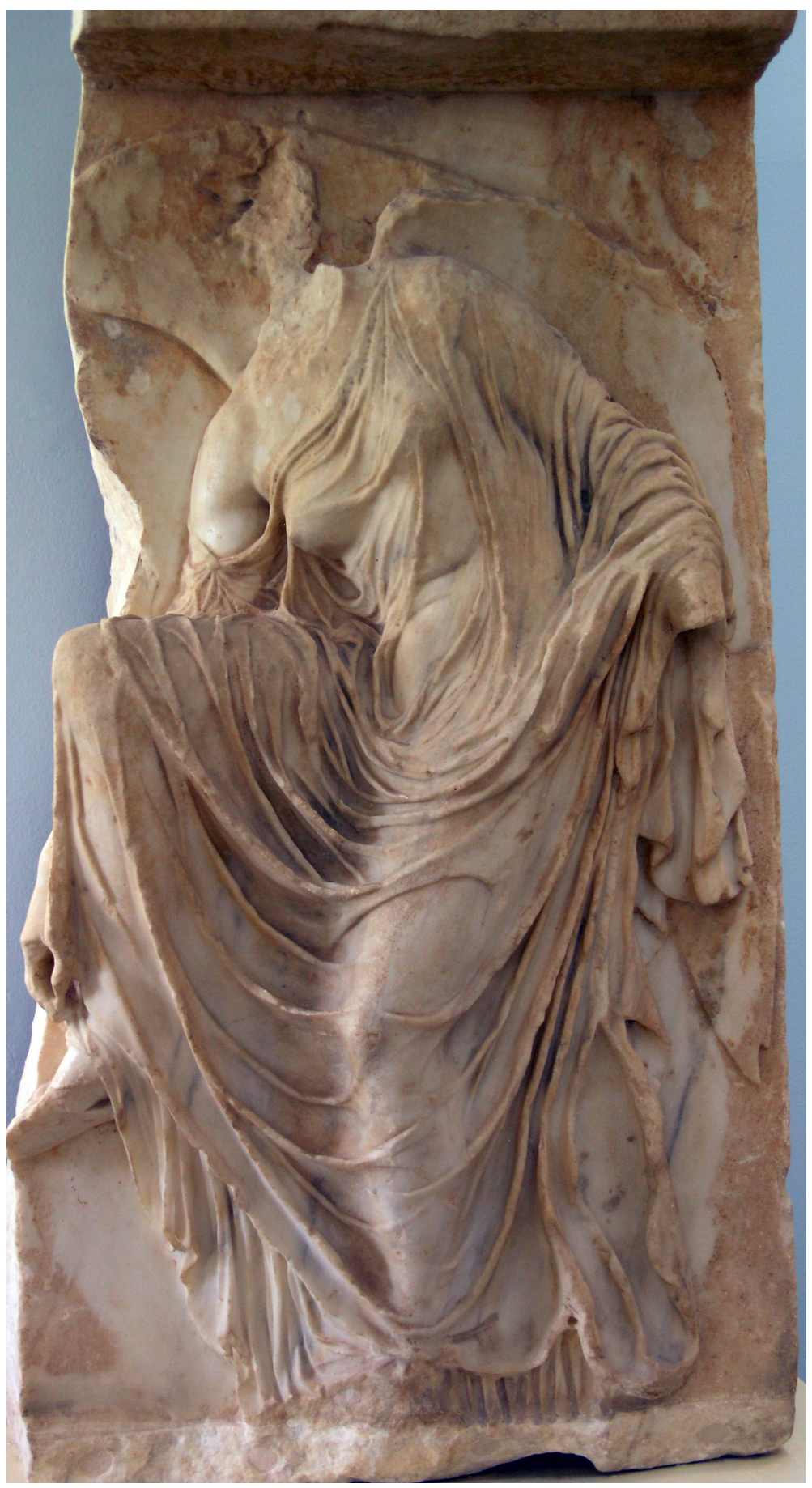

Figure 21. Nike Adjusting her Sandal. 
Goddess of Love as his metaphor and muse to initiate the aforementioned dialogue between statue and viewer that is centered on a sensual topic. This statue opened doors for new works of art, wherein the role of women was recognized and celebrated. Indeed, Praxiteles was the first sculptor to brave the uncharted waters of portraying the nude female, which was a huge success. Her beauty, femininity, and sexuality no doubt created intrigue, shock, and drama. These combined elements worked together to inspire future artists to celebrate the female nude. This new trend broke down the barrier and allowed women to be depicted in the nude, removing the status of "lowlifes" like prostitutes or victims. Aphrodite, the Goddess of Love, encourages the viewer to enjoy her nudity while inviting us to voyeuristic pleasures! The Aphrodite of Knidos, on any level, acts as a trendsetter in her shedding of drapery and thus earlier established traditions.

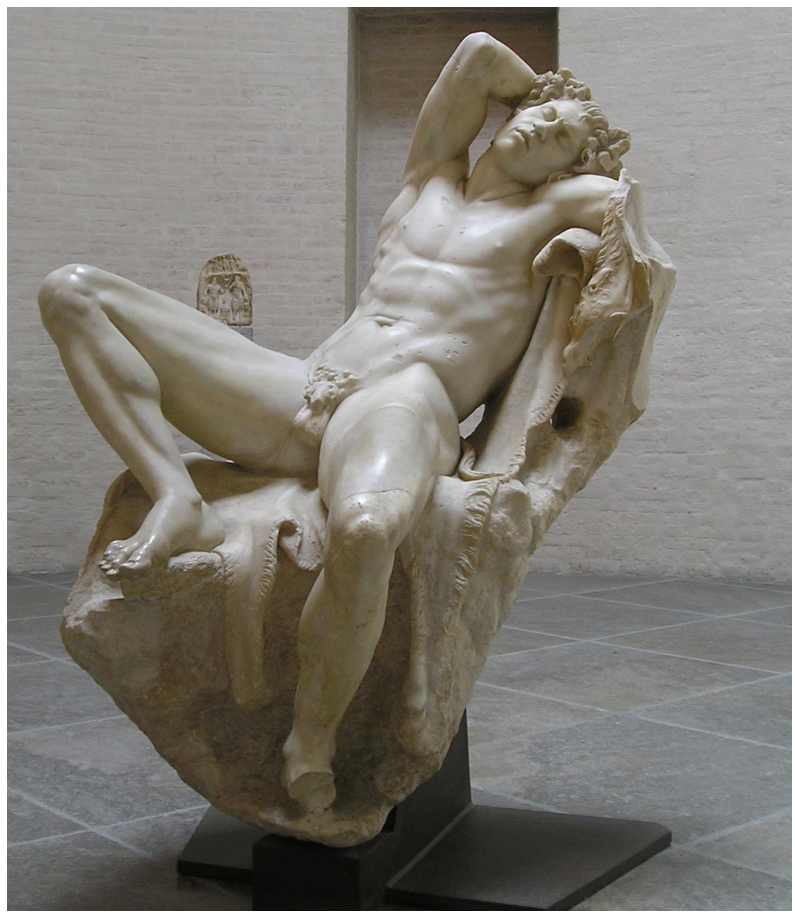

Figure 22. Barberini Faun. 


\section{Bibliography}

Antonio, Corso. "Aphrodite of Cnidus." Encyclopaedia of the Hellenic World, Asia Minor. (2002): Section 8.3. Accessed Apr. 22, 2016. http://asiaminor.ehw.gr/forms/ fLemmaBodyExtended.aspx?lemmaID=3876.

Bahrani, Zainab. "The Hellenization of Ishtar: Nudity, Fetishism, and the Production of Cultural Differentiation in Ancient Art." Oxford Art Journal 19, no. 2 (1996): 3-16. Accessed Oct. 22, 2015. http://www.jstor.org/stable/1360725.

Barrow, Rosemary. "From Praxiteles to De Chirico: Art and Reception.” International Journal of the Classical Tradition 11, no. 3 (2005): 344-368. Accessed Nov. 12, 2015. http://www.jstor.org/stable/30221988.

Cyrino, Monica Silveira. “' 'Shame, Danger and Desire': Aphrodite's Power in the Fifth Homeric Hymn.” Rocky Mountain Review of Language and Literature 47, no. 4 (1993): 219-230. Accessed Mar. 6, 2016. http://www.jstor.org/stable/1348308.

Eck, Beth A. "Men Are Much Harder: Gendered Viewing of Nude Images." Gender and Society 17, No. 5 (2003): 691-710. Accessed Oct. 30, 2015. http://www.jstor. org/stable/3594705.

Gregory, Sharon. "Caravaggio and Vasari’s 'Lives.' " Artibus et Historiae 32, no. 64 (2011): 167-191. Accessed Apr. 13, 2016 http://www.jstor.org.proxy.lib.pdx. edu/stable/41479760.

Havelock, Christine Mitchell. The Aphrodite of Knidos and Her Successors: A Historical Review of the Female Nude in Greek Art. Ann Arbor: University of Michigan, 1995.

Irving, Jenni. "Greek Women Classical to Hellenistic: A Brief Discussion of Changing Factor." GraecoMuse. 2013. Accessed Apr. 15, 2016. https:/graecomuse.wordpress.com/2013/ 01/11/greek-women-classical-to-hellenistic-a-brief-discussion-of-changing-factors. 
Kampen, Natalie Boymel. "Epilogue: Gender and Desire." In Naked Truths: Women, Sexuality, and Gender in Classical Art and Archaeology, edited by Ann Olga Koloski-Ostrow, and Claire L. Lyons, 197-219. London: Routledge, 1997.

Kampen, Natalie Boymel. “Gauging the Gender Gap.” The Women's Review of Books 15, no. 5 (1998): 32. Accessed Mar. 31, 2016. doi: 10.2307/4022863.

Lamar, Londyn. “Aphrodite and her Famous Nudity.” Heritage Daily. May 28, 2013. Accessed Nov. 22, 2015. http://www.heritagedaily.com/2013/05/aphrodite-and-herfamous-nudity/89666.

Lee, Mireille M. Body, Dress, and Identity in Ancient Greece. New York: Cambridge University Press, 2015. Accessed Mar. 10, 2016. http://orbis.eblib.com.proxy.lib.pdx.edu.

Love, Iris Cornelia. "A Preliminary Report of the Excavations at Knidos, 1969.” American Journal of Archaeology 74, no. 2 (1970): 149-155. Accessed Oct. 22, 2015. doi: $10.2307 / 503205$.

Lucian (attributed). Amores. Translated by A.M. Harmon. Loeb edition. Accessed Apr. 18, 2016. http://www.well.com/user/aquarius/lucian-amores.htm.

Miner, Jess. “Courtesan, Concubine, Whore: Apollodorus' Deliberate Use of Terms for Prostitutes." The American Journal of Philology 124, no. 1 (2003): 19-37. Accessed Mar. 12, 2016. http://www.jstor.org.proxy.lib.pdx.edu/stable/1561932.

Oakley, John H. “Greek Vase Painting.” American Journal of Archaeology 113, no. 4 (2009): 599-627. Accessed Mar. 1, 2016. http://www.jstor.org/stable/20627620.

Ridgway, Brunilde Sismondo. Fourth-Century Styles in Greek Sculpture. Madison: University of Wisconsin Press, 1997.

Salomon, Nanette. "Making a World of Difference.” In Naked Truths: Women, Sexuality, and Gender in Classical Art and Archaeology, edited by Ann Olga Koloski- 
Ostrow, and Claire L. Lyons, 197-219. London: Routledge, 1997.

Sissa, Guilia. "Maidenhood without Maidenhead: The Female Body in Ancient Greece.” In Before Sexuality: The Construction of Erotic Experience in the Ancient Greek World, edited by David M. Halperin, John J. Winkler, and Froma I. Zeitlin, 339-364. Princeton, N.J.: Princeton University Press, 1990.

Smith, Amy Claire, and Sadie Pickup. Brill's companion to Aphrodite. Leiden: Brill, 2010.

Squire, Michael. The Art of the Body: Antiquity and its Legacy. Oxford: University Press, 2011.

Stehle, Eva and Amy Day. "Women Looking at Women: Women's Ritual and Temple Sculpture.” In Sexuality in Ancient Art, edited by Natalie Boymel Kampen, 101116. Cambridge: Cambridge University Press, 1996.

Stewart, Andrew. Greek Sculpture: An Exploration. New Haven and London: Yale University Press, 1990.

Sutton, Robert F., Jr. "Pornography and Persuasion on Attic Pottery.” In Pornography and Representation in Greece and Rome, edited by Amy Richlin, 3-35. New York and Oxford: Oxford University Press, 1992.

Webb, Peter. "Erotic Art." Grove Art Online. Oxford Art Online. Oxford University Press. Last modified May 28, 2015. Accessed Mar. 4, 2016. http://www. oxfordartonline.com.proxy.lib.pdx.edu/subscriber/article/grove/art/T026580.

Young, Philip H. "The Cypriot Aphrodite Cult: Paphos, Rantidi, and Saint Barnabas.” Journal of Near Eastern Studies 64, no. 1. (2005): 23-44. Accessed Mar. 5, 2016. doi: $10.1086 / 429165$. 


\section{Citations of Images}

Buell 31

Figure 1. Kleomelos Painter, Discus Player. 510-500 все, terracotta, diameter: $19.8 \mathrm{~cm}$. Louvre Museum, France. Available from: https://commons.wikimedia.org (accessed Apr. 7, 2016).

Figure 2. Foundry Painter, Pankration Foul (kylix). 490-480 вСE, terracotta, diameter, $31.8 \mathrm{~cm}$. British Museum, England. Available from: https://commons.wikimedia. org (accessed Apr. 23, 2016).

Figure 3. Doryphoros. 120-50 всE, marble, 2.12 m. Naples National Archaeological Museum, Italy. Available from https://www.oneonta.edu (accessed Apr. 14, 2016).

Figure 4. Aphrodite Sosandra. 460 все, marble. Naples National Archaeological Museum, Italy. Available from: https://commons.wikimedia.org (accessed May 4, 2016).

Figure 5. Aphrodite of Knidos (front view). Marble, life sized. Vatican Museums, Italy. Available from: https://www.oneonta.edu (accessed Mar. 23, 2016).

Figure 6 Aphrodite of Knidos (back view). Marble, life sized. Vatican Museums, Italy. Available from http://www.thehistoryblog.com (accessed Apr. 12, 2016).

Figure 7. Aphrodite of Knidos (side view). Marble, life sized. Vatican Museums, Italy. Available from: https://www.studyblue.com (accessed Apr. 12, 2016).

Figure 8. Onesimos, Woman Playing a Game. 500 всE, terracotta. The Getty, United States. Available from: http://blogs.getty.edu (accessed May 31, 2016).

Figure 9. Three Women Bathing. 440-430 все, terracotta. Staatliche Antikensammlungen, Germany. Available from: https://commons.wikimedia.org (accessed Apr. 23, 2016).

Figure 10. Roman coin depicting the Aphrodite of Knidos. Silver. American Numismatic Society, New York. Available from: http://members.bib-arch.org (accessed Apr. 7, 2016). 
Buell 32

Figure 11. Hydria (water jar): Family Scene. 440-430 все, terracotta, height: $34.6 \mathrm{~cm}$; diameter with handles: $30.2 \mathrm{~cm}$. Harvard Art Museums, Massachusetts. Available from: http://www.harvardartmuseums.org (accessed Apr. 5, 2016).

Figure 12. Knidos, Turkey. Sailing Britican. Available from: http://www.sailingbritican.com (accessed Apr. 7, 2016).

Figure 13. Kylix depicting Ajax the Lesser Raping Cassandra. 440-430 все, terracotta, diameter $32.6 \mathrm{~cm}$. Louvre Museum, France. Available from: https://commons. wikimedia.org (accessed May 8, 2016).

Figure 14. Kylix depicting Greek scene of erotisicm and violence. 490-480 все, terracotta. Archaeological Museum, Italy. Available from: http://www.ancient.eu/image/640 (accessed May 8, 2016).

Fig. 15. The Birth of Aphrodite. 370-360 все, terracotta. Naples National Archaeological Museum, Italy. Available from: http://www.theoi.com (accessed Apr. 9, 2016).

Figure 16. Hestia, Dione, and Aphrodite, from Parthenon East Pediment. 447-432 все, marble, 1.73 m x 3.15 m. The British Museum, England. Available from: https:// commons.wikimedia.org (accessed Apr. 5, 2016).

Figure 17. Aphrodite, Pan, and Eros. 100 вCE, marble, 1.55 m. National Archaeological Museum, Greece. Available from: http://www.namuseum.gr (accessed Mar. 23, 2016).

Figure 18. Capitoline Aphrodite. Marble, $193 \mathrm{~cm}$. Musei Capitolini, Italy. Available from: http://en.museicapitolini.org (accessed Mar. 23, 2016).

Fig. 19. Medici Aphrodite. 1st century ce, marble. Galleria degli Uffizi, Italy. Available from: https://commons.wikimedia.org (accessed Mar. 23, 2016). 
Buell 33

Figure 20. Female Figurine. 8th century BCE, ivory. The National Museum of Iraq, Iraq. https://www.pinterest.com (accessed Apr. 9, 2016).

Figure 21. Nike Adjusting her Sandal. 420-410 BCE. Acropolis Museum, Italy. Available from: https://commons.wikimedia.org (accessed May 19, 2016).

Figure 22. Barberini Faun. c. 220 вCE, marble, life sized. Glyptothek, Germany. Available from: https://wordpress.com (accessed May 7, 2016). 